\title{
Emerging therapeutic agents for advanced non-small cell lung cancer
}

\author{
Ruqin Chen, Rami Manochakian, Lauren James, Abdel-Ghani Azzouqa, Huashan Shi, Yan Zhang, Yujie Zhao,
} Kexun Zhou and Yanyan Lou ${ }^{*}$ (D)

\begin{abstract}
Advanced non-small cell lung cancer (NSCLC) is the most common type of lung cancer, with a poor prognosis and no known cure. Survival time is often short because of limited treatment options. Recent advances in targeted therapy and immunotherapy have changed the landscape for the treatment of advanced NSCLC. In the last 10 years, the US Food and Drug Administration (FDA) has approved more than 17 new medications for this devastating disease and more are coming. Molecular and immunogenic testing makes personalized medicine possible for patients with advanced NSCLC. The new medications provide promising efficacy and safety resulting in improved long-term survival for a significant number of patients. In this review, we summarize the recent advances in advanced/metastatic NSCLC therapeutics with a specific focus on first in-human or early-phase I/II clinical trials. These drugs either offer better alternatives to current standard drugs in the same class or are a completely new class of drugs with novel mechanisms of action. Advances are divided into (1) targeted agents, (2) antibody-drug conjugates, and (3) immunotherapies. Finally, we present a brief review of the emerging agents and ongoing clinical studies.
\end{abstract}

Keywords: Advanced non-small cell lung cancer, NSCLC, Emerging therapeutic agents, Targeted therapy, Immunotherapy, Clinical trials

\section{Introduction}

Lung cancer is the most common cause of cancerrelated death and the second most common malignancy reported in the USA and worldwide. It is estimated that in 2020 there will be 228,820 newly diagnosed cases of lung cancer and 135,720 deaths attributed to lung cancer. The total number of deaths attributed to lung cancer is greater than from colon, prostate, and breast cancer combined. This dismal outcome in lung cancers is due, in part to the fact that more than half of the patients, about $55 \%$, presented with metastatic lung cancer at the time of diagnosis [1]. Finally, non-small cell lung cancer (NSCLC) comprised about $85 \%$ of the newly diagnosed lung cancer cases. Advanced NSCLC includes

\footnotetext{
* Correspondence: Lou.yanyan@mayo.edu

Division of Hematology and Oncology, Mayo Clinic, Jacksonville, FL 32224, USA
}

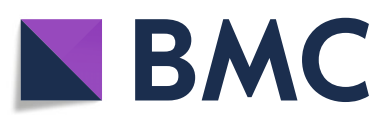

( The Author(s). 2020 Open Access This article is licensed under a Creative Commons Attribution 4.0 International License, which permits use, sharing, adaptation, distribution and reproduction in any medium or format, as long as you give appropriate credit to the original author(s) and the source, provide a link to the Creative Commons licence, and indicate if changes were made. The images or other third party material in this article are included in the article's Creative Commons licence, unless indicated otherwise in a credit line to the material. If material is not included in the article's Creative Commons licence and your intended use is not permitted by statutory regulation or exceeds the permitted use, you will need to obtain permission directly from the copyright holder. To view a copy of this licence, visit http://creativecommons.org/licenses/by/4.0/. The Creative Commons Public Domain Dedication waiver (http://creativecommons.org/publicdomain/zero/1.0/) applies to the data made available in this article, unless otherwise stated in a credit line to the data. lowing initial definitive treatment.

Median overall survival (OS) for metastatic NSCLC patients is about 4-5 months with supportive care alone. For patients that receive supportive care in conjunction with induction platinum-based chemotherapy, historically, the median OS has been 8-12 months. For decades, multiple trials have compared different chemotherapy regimens and resulted in marginal improvements in the OS $[2,3]$. Research examining the treatment benefits of chemotherapy has plateaued. In 2002, the Eastern Cooperative Oncology Group published results of a randomized phase III trial comparing four platinum-based doublets in first-line metastatic NSCLC. The trial demonstrated no difference in overall survival among the different treatment regimens. 
In 2004, a randomized phase II trial comparing chemotherapy versus bevacizumab plus chemotherapy reported results that showed that NSCLC patients with non-squamous type responded better to bevacizumab with chemotherapy. Similarly, the impact of histology to treatment was also seen with pemetrexed. Pemetrexed was shown to only be effective in nonsquamous cell carcinoma. Finally, results from a phase 3 trial examining platinum-based chemotherapy followed by maintenance pemetrexed showed a median OS rate of 13.9 months, as compared with 11 months among patients randomly assigned to supportive care alone after induction chemotherapy. Median OS from induction in patients received pemetrexed was 16.9 months compared to 14 months in patients without supportive care alone [4-6].

A major advancement in the treatment of metastatic NSCLC came with the identification of specific driver mutations and the development of targeted therapy. Although the subset of patients with actionable mutations is small, progression-free survival was shown to be significantly increased in patients treated with targeted therapy compared to those treated with chemotherapy. The response rate range is 50 to $80 \%$ for patients who harbored EGFR, ALK, ROS1, and BRAF mutations and received targeted therapy. Overall survival was increased to between 18 and 38.6 months [7-9].

The development of immune checkpoint inhibitors was the next breakthrough in the treatment of metastatic NSCLC. Research has shown that inhibitors of programmed death 1 (PD-1) and the ligand PD-L1 are effective in metastatic NSCLC as first-line and secondline treatment options. Nivolumab, an immune checkpoint inhibitor, was the first approved second-line treatment in immunotherapy for metastatic NSCLC. Nivolumab, when compared with docetaxel, improved the median OS in squamous and non-squamous NSCLC. Additionally, pembrolizumab was approved as a single agent for first-line treatment and showed a higher OS rate at 6 months than chemotherapy alone among patients with high PD-L1 level $>50 \%$ who did not have targetable mutations.

Recent studies demonstrate that pembrolizumab in combination with chemotherapy improved the OS irrespective of PD-L1 status when compared to chemotherapy alone; in both non-squamous and squamous histology types. For patients with non-squamous subtype, receiving pembrolizumab in combination with chemotherapy, the hazard ratio for death was 0.49 with a 12-month OS rate of $69.2 \%$. For patients with the squamous subtype, who received pembrolizumabchemotherapy combination, the hazard ratio for death was 0.64 with a median OS of 15.9 months. Before the introduction of immunotherapy with checkpoint inhibitors, the 5-year survival rate for patients with advanced NSCLC was 4-6\%. Long-term survival significantly improved with the addition of immunotherapy. A phase I trial examining the efficacy of nivolumab as a second-line treatment, resulted in increasing the estimated 5-year overall survival rate to $16 \%$ [10]. In another phase I trial, examining the efficacy of pembrolizumab, the 5 -year overall survival was $23.3 \%$ in first-line setting and $15.5 \%$ in the second-line setting. Among patients with a PD-L1 $>50 \%$ treated with pembrolizumab, 5 -year overall survival is more than $25 \%$ in both first- and second-line setting [11].

In the past decade, treatments for advanced NSCLC have dramatically evolved and enabled more individualized selection of treatment options. Molecular profiles and immunologic status help to determine treatment options. For example, patients who harbor EGFR mutations, ALK rearrangement, ROS1 rearrangement, BRAF mutation, NTRK mutation, and high PD-L1 level should have FDA-approved targeted therapy or immunotherapy as first line. Other oncologic driver mutations such as RET, MET, and HER2 in NSCLC are also promising targets for treatment. Immunologic blockades to PD-1, PDL1, and CTLA-4 are also blooming.

This paper reviews recently published data on some of the most promising lines of treatment. We reviewed currently approved and emerging systemic therapies for advanced NSCLC. A literature search was done in PubMed, Google Scholar, ClinicalTrial.gov, American Society of Clinical Oncology (ASCO) meeting abstracts, World Conference on Lung Cancer (WCLC) abstracts, and American Association for Cancer Research (AACR) abstracts to identify phase $1 / 2$, first in human clinical trials in advanced/metastatic non-small cell lung cancer. Each study was individually reviewed and data points have been summarized (Table 6).

\section{Targeted therapy}

Epidermal growth factor receptor (EGFR) tyrosine kinase inhibitors (TKIs)

EGFR belongs to a family of receptor tyrosine kinase that includes EGFR/ERBB1, HER2/ERBB2/NEU, HER3/ ERBB3, and HER4/ERBB4.

EGFR mutations are present in $15 \%$ of patients with NSCLC in the Western population and rising to $35 \%$ in the Asian population. Additionally, there is a higher prevalence of EGFR mutations in never smokers. These mutations occur within EGFR exons 18-21 and about $90 \%$ of these mutations are exon 19 deletions or exon 21 L858R point mutations, which refer to EGFR mutant as above. These mutations are sensitive to EGFR TKIs. EGFR mutations on exon 18 and exon 20 are usually less sensitive to EGFR TKIs. 
Table 1 FDA-approved EGFR TKls

\begin{tabular}{|c|c|c|c|}
\hline Drug & Month/year & Indication & Comments \\
\hline Erlotinib & May/2013 & 1st line metastatic EGFR mutant & $\begin{array}{l}\text { First generation. Approved } 18 \text { November } 2004 \text { for 2nd-line metastatic } \\
\text { NSCLC. } 10 \text { April } 2010 \text { maintenance }\end{array}$ \\
\hline Gefitinib & July/2015 & 1st line metastatic EGFR mutant patients & Approved in 2003 as third line, retracted approval 2005 \\
\hline \multirow[t]{2}{*}{ Afatinib } & July/2013 & 1st line metastatic EGFR mutant & Second generation \\
\hline & January/2018 & $\begin{array}{l}\text { 1st line metastatic EGFR non-resistant } \\
\text { mutations }\end{array}$ & \\
\hline \multirow[t]{2}{*}{ Osimertinib } & $\begin{array}{l}\text { November/ } \\
2015\end{array}$ & $\begin{array}{l}\text { EGFR T790M mutation after progressed } \\
\text { on EGFR TKI }\end{array}$ & Third generation. With CNS penetration \\
\hline & April/2018 & 1st line metastatic EGFR mutant patients & \\
\hline Dacomitinib & $\begin{array}{l}\text { September/ } \\
2018\end{array}$ & 1st line metastatic EGFR mutant patients & Second generation \\
\hline
\end{tabular}

Gefitinib is the first tested EGFR inhibitor in advanced NSCLC. Iressa Pan-Asia Study (IPASS) reported progression-free survival was significantly longer among those who received gefitinib than among those who received chemotherapy (hazard ratio for progression or death, 0.48). However, erlotinib is the first approved in the USA for this indication.

As of today, gefitinib, erlotinib, afatinib, dacomitinib, and osimertinib are all FDA-approved first-line treatment of patients with metastatic NSCLC whose tumors have EGFR exon 19 deletions or exon 21 L858R mutations (Table 1). Afatinib was also active in non-small cell lung cancer tumors that harbored certain types of uncommon EGFR mutations, especially Gly719Xaa, Leu861Gln, and Ser768Ile, but less active in other mutations types.

In a phase 3 clinical trial, osimertinib significantly prolonged progression-free survival to 18.9 months as compared to 10.2 months for patients with untreated EGFRmutated advanced NSCLC received gefitinib or erlotinib. The response rate, $76-80 \%$, is similar for all three agents. However, the duration of response is much longer with osimertinib (17.2 months) than with gefitinib/erlotinib (8.5 months). Additionally, grade 3 or 4 adverse events are less frequently reported with osimertinib when compared with gefitinib/erlotinib. Recently, results from FLAURA study revealed that the median overall survival was 38.6 months in patients who received osimertinib in comparison to 31.8 months in patients who received gefitinib/erlotinib. These results indicate osimertinib demonstrates better efficacy and less side effects, as well as CNS penetration, making it the new standard first-line treatment for mutated EGFR advanced NSCLC patients [9].

Nazartinib (EGF816), BPI-7711, lazertinib (YH25448), and HS-10296 are all third-generation oral EGFR TKIs selective for activating (L858R, ex19del) and resistance (T790M) mutants.

In a phase II trial, 40 treatment-naïve EGFR mutant advanced NSCLC patients received $150 \mathrm{mg}$ of oral nazartinib daily; 16 of the 40 patients (40\%) had brain metastases. The objective response rate (ORR) was $67 \%$ (1 CR/15 PRs); disease control rate was 96\%. Duration of response and progression-free survival (PFS) data were still immature at the data cut-off. The most common adverse events were maculopapular rash, diarrhea, and stomatitis [12].

A phase I trial examining the benefit of treatment with BPI-7711, that included 85 patients with advanced or recurrent EGFRm+/T790M+ NSCLC who had progressed after 1st/2nd generation of EGFR TKIs were enrolled into 5 dose escalation cohorts $(30 / 60 / 120 / 180 / 240 \mathrm{mg})$. No DLT was observed. The most common adverse events were white blood cell count decrease, neutrophil count decrease, upper respiratory infection, vomiting, and diarrhea. Serious adverse events were reported in $4 \%$ of patients. Fifty-five patients were available for efficacy evaluation. The ORR was $54.5 \%$ (30/55) including $1.8 \% \mathrm{CR}$ and $52.7 \%$ PR. The disease control rate was 96.4\% [13].

A total of 127 EGFRm and T790M resistance advanced NSCL patients who progressed after treatment with standard EGFR TKIs were enrolled into a phase I/II trial of $\mathrm{YH} 25448$. The treatment dose of $\mathrm{YH} 25448$ ranged from 20 to $320 \mathrm{mg}$. No DLT was observed. The most common adverse events were pruritus, decreased appetite, rash, and constipation. Grade 3 or higher adverse events were observed in $3 \%$ of patients. Median duration of treatment was 9.7 months. In patients evaluated for efficacy, the ORR was $60 \%$. The ORR was $64 \%$ in T790M-positive patients compared with $37 \%$ of patients in T790M negative. The ORR was $50 \%$ in patients with brain metastasis $(n=14)$. The median PFS was 8.1 months in all patients, 9.5 months in T790M-positive patients, and 5.4 months for T790M negative patients. In patients who received higher than $120 \mathrm{mg}$ doses, the ORR was $65 \%$ and the PFS was 12.2 months [14].

In a phase I trial examining the treatment benefits of HS-10296, a total 117 patients with EGFRm and T790M 
resistance advanced NSCL patients who progressed after treatment with standard EGFR TKIs were enrolled. The treatment dose of HS-10296 ranged from 55 to $260 \mathrm{mg}$. The MTD has not been reached and the most common adverse events were rash, pyrexia, upper respiratory tract infection, constipation, and diarrhea. Efficacy was evaluated in 82 patients. The ORR was $52.5 \%$ and the disease control rate (DCR) was $91.5 \%$. The DCR in patients receiving $110 \mathrm{mg}$ improved to $97.2 \%$. Thus, the recommended phase II dose was $110 \mathrm{mg}$ [15].

\section{EGFR TKIs targeting exon 20}

Patients with EGFR/HER2 exon 20 mutations account for about $10 \%$ of all EGFR-mutated NSCLC. The presence of these mutations usually confers primary resistance to TKIs.

Recently, two new targeted agents showed activity in this subtype of NSCLC, TAK-788, and poziotinib. TAK788 is an investigational TKI that inhibits the EGFR and HER2 receptors. In a phase I/II clinical trial, 101 patients received TAK-788 treatment. The treatment dose of TAK-788 ranged from 5 to $180 \mathrm{mg}$. The phase II recommended dose was $160 \mathrm{mg}$. Efficacy was evaluable in 24 patients with EGFR exon 20 insertions. Twenty-three had decreased target lesion measurements with median percent change of $32.6 \%$. The ORR was $54 \%$ in patients that received $160 \mathrm{mg}$. Adverse event profile was similar with other EGFR TKIs [16, 17].

A phase II clinical trial with poziotinib enrolled 50 patients in an EGFR cohort; 40 patients were evaluable for response. The overall response rate is $58 \%$ and the DCT was $90 \%$. Eight out of 13 responders (62\%) were previously treated with a TKI. Thirteen patients enrolled to the HER2 cohort and 12 patients were evaluated for response. The ORR was $50 \%$ and the DCR is $83 \%$ (World Lung 2018 Abstract OA02.06).

\section{Resistance after EGFR TKIs treatment}

Most of the patients who received EGFR TKIs with initial response will eventually develop disease progression. For patients who had disease progression after gefitinib, erlotinib, or afatinib, about half of the patients develop resistance related to EGFR T790M. Patient usually will be given osimertinib to overcome EGFR T790 M resistance.

For patients who had disease progression after osimertinib, there is EGFR-dependent and EGFR-independent resistance. In EGFR-dependent resistance, about half of the patient lost EGFR-T790M mutation.

The second common mechanism of resistance is acquired amplification of MET which could occur in about $16 \%$ of patients who had disease progression after gefitinib or erlotinib, and it could happen up to $30 \%$ of patients who treated after osimertinib. The other resistance mechanisms to EGFR TKIs therapy include
HER2 amplification, RAS/MAPK/PI3K pathway activation, cell cycle gene alteration, and transformation of into small cell lung cancer [18-20].

For patients who have progressed after osimertinib, there is no FDA-approved targeted therapy. The current standard is to give chemotherapy or chemotherapy plus immunotherapy such as IMpower 150 regimen.

For patients who had progressed after osimertinib with MET-driven acquired resistance, a phase Ib SAVANNAH study showed an efficacy of osimertinib plus MET inhibitor with ORR 64-66\%. However, there are about $38-57 \%$ of patients experienced grade 3 or more adverse events. Some patients experience anaphylactic reaction related to savolitinib. Currently, phase II SAVANNAH study is on hold due to safety concerns [21].

\section{ALK fusion/rearrangement inhibitors}

The EML4 and ALK genes are within the short arm of chromosome 2; inversion of these 2 genes resulted in the novel fusion oncogene EML4-ALK. It is found approximately in $2-7 \%$ of advanced NSCLC patients, typically in younger and never smokers $[22,23]$.

Crizotinib is the first approved targeted therapy for ALK-positive advanced NSCLC. It has shown prolonged PFS when compared with chemotherapy. The median PFS with Crizotinib is 10.9 months versus 7.0 months with chemotherapy [24]. However, resistance invariably develops and crizotinib has poor CNS penetration as well. Newer generations of ALK inhibitors are more potent than crizotinib and can overcome the resistance (Table 2). ALK inhibitors, such as alectinib, brigatinib, and lorlatinib also showed intracranial efficacy.

Currently, the preferred first-line treatment is alectinib based on the ALEX trial. A total of 303 untreated ALKpositive advanced NSCLC patients were randomized to receive either alectinib or crizotinib. The 12-month event-free survival rate was $68.4 \%$ with alectinib compared to $48.7 \%$ with crizotinib. The median PFS was 34.8 months with alectinib and 10.9 months with crizotinib. The PFS hazard ratio was 0.43 . The median PFS with baseline CNS metastasis was 27.7 months with alectinib in comparison to 7.4 months with crizotinib. Alectinib was also better tolerated than crizotinib $[25,26]$.

Brigatinib is another next-generation ALK inhibitor that showed improved PFS over crizotinib, with an estimated 12-month PFS of $67 \%$ compared to crizotinib 12 month PFS of $43 \%$. The hazard ratio with brigatinib was 0.49 . The confirmed ORR was $71 \%$ with brigatinib compare to $60 \%$ with crizotinib. The intracranial response rate was $78 \%$ over $29 \%$, respectively. No new safety concerns were reported [27]. 
Table 2 FDA-approved ALK TKIs

\begin{tabular}{|c|c|c|c|}
\hline Drug & Month/year & Indication & Comments \\
\hline Crizotinib & August/2011 & Metastatic ALK+ NSCLC & First generation \\
\hline Ceritinib & April/2014 & Metastatic ALK+ NSCLC & $\begin{array}{l}\text { Second } \\
\text { generation }\end{array}$ \\
\hline \multirow[t]{2}{*}{ Alectinib } & $\begin{array}{l}\text { December/ } \\
2015\end{array}$ & Metastatic ALK+ NSCLC who have progressed on or are intolerant to crizotinib & $\begin{array}{l}\text { Second } \\
\text { generation }\end{array}$ \\
\hline & $\begin{array}{l}\text { November/ } \\
2017\end{array}$ & Metastatic ALK+ NSCLC & \\
\hline Brigatinib & April/2017 & Metastatic ALK+ NSCLC who have progressed on or are intolerant to crizotinib & $\begin{array}{l}\text { Second } \\
\text { generation }\end{array}$ \\
\hline Lorlatinib & $\begin{array}{l}\text { November/ } \\
2018\end{array}$ & $\begin{array}{l}\text { Metastatic ALK+ NSCLC who has progressed on alectinib or ceritinib, or crizotinib and at least one } \\
\text { other ALK inhibitor }\end{array}$ & Third generation \\
\hline
\end{tabular}

Finally, ceritinib is more potent than crizotinib and showed efficacy in patients who have progressed on crizotinib. However, ceritinib was not compared head-tohead with crizotinib in the first-line setting [28].

Lorlatinib is a third generation inhibitor of ALK and ROS1. In a phase II trial, a subgroup of 198 advanced ALK-positive NSCLC patients who had progressed on one or more ALK inhibitors were enrolled. The ORR was $47 \%$. Objective intracranial response was $63 \%$. The most common adverse effects were hypercholesterolemia, hypertriglyceridemia, edema, and peripheral neuropathy. Serious adverse events occurred in $7 \%$ of patients [29].

Ensartinib (X-396) is a potent ALK TKI and has also shown inhibitory activity against MET, BAL, Axl, EPHA2, LTK, ROS1, and SLK. In a phase I/II study, 97 patients with advanced ALK-positive NSCLC were enrolled and given ensartinib $225 \mathrm{mg}$ once daily. Common toxicities were rash, nausea, pruritus, vomiting, and fatigue. For evaluable patients, the response rate was $60 \%$ and the median PFS was 9.2 months. For ALK TKI naïve patients, RR was $80 \%$ and median PFS was 26.2 months. Patients with brain metastases were observed with intracranial RR of 64\% [30]. A phase III clinical trial to compare ensartinib to crizotinib in ALK-positive NSCLC patients is currently open and enrolling patients [31].

\section{ROS1/NRTK inhibitor}

ROS1

ROS1 rearrangement accounts for about $1-2 \%$ in NSCLC and typically occurs in younger patients who are never smokers. The ROS1 locus is located on chromosome 6 and encodes for a tyrosine kinase receptor.

Crizotinib was approved for metastatic ROS1 positive NSCLC in March 2016 (Table 3). In an ongoing phase I study, crizotinib showed anti-tumor activity in patients with ROS1 positive advanced NSCLC with the ORR was $72 \%$ and median duration of response was 17.6 month. Median PFS was 19.3 months. Median OS was 51.4 months [32].
Ceritinib and lorlatinib were not approved in metastatic ROS1 +NSCLC yet but both showed anti-tumor activity in this patient population. In a phase II trial conducted in Korea, 32 patients with ROS1 positive advanced NSCLC were treated with ceritinib. Two patients had previously received crizotinib while 30 patients were crizotinib naïve. Twenty-eight patients were evaluated for efficacy. The ORR was $62 \%$ and the DCT was $81 \%$. The median PFS was 9.3 months for all patients and 19.3 months for crizotinib naïve patients. The median OS was 24 months [33].

In a phase II trial, lorlatinib was given to $47 \mathrm{pa}$ tients with ROS1+ advanced NSCLC. Thirty-four patients were previously treated with crizotinib and 13 patients were crizotinib naïve. Twenty-five patients had baseline CNS metastases. The ORR was $36.2 \%$ in all patients and $61.5 \%$ in crizotinib naïve patients. The intracranial ORR was $56 \%$ in all patients. The median PFS was 9.9 months in all patients and 21 months in crizotinib naïve patients [34].

\section{NTRK}

NTRK gene fusions involve either NTRK1, NTRK2, or NTRK3 and occurs across tumor types. These fusions account for about $1 \%$ in NSCLC. The first approved oral TKI for NRTK was larotrectinib. Larotrectinib is approved for advanced or metastatic solid tumors that harbor the NTRK fusion genes with conditions found in Table 3. A trial that combines 3 phase I/II trials reported integrative efficacy and safety for larotrectinib in NTRK fusion-positive cancers in adults and children. The ORR was $75 \%$. The median duration of response and PFS were not reached. Most treatment-emergent adverse events (TEAEs) were grade 1 , and grade $3 / 4$ TEAEs were reported in less than $5 \%$ of patients [35].

Entrectinib is an oral TKI for ROS1, ALK, and NTRK gene fusions. Entrectinib was first approved in Japan in June 2019 for the treatment of adult and pediatric advanced or recurrent NSCLC with NTRK fusions. Recently, the FDA-approved entrectinib for similar indication as 
Table 3 FDA-approved ROS1 TKI and NTRK TKI

\begin{tabular}{llll}
\hline Drug & $\begin{array}{l}\text { Month/ } \\
\text { year }\end{array}$ & Indication & Comments \\
\hline Crizotinib & $\begin{array}{l}\text { March/ } \\
2016\end{array}$ & Metastatic ROS1 +NSCLC & \\
Larotrectinib & $\begin{array}{l}\text { November/ } \\
2018\end{array}$ & $\begin{array}{l}\text { Advanced or metastatic NTRK gene fusion Solid tumors, no acquired resistance mutation, and have } \\
\text { no satisfactory alternative treatments available }\end{array}$ & $\begin{array}{l}\text { Adult and } \\
\text { pediatric patients }\end{array}$ \\
Entrectinib & $\begin{array}{l}\text { August/ } \\
2019\end{array}$ & $\begin{array}{l}\text { Adult metastatic ROS1 +NSCLC, adult and pediatric patients 12 years of age and older with advanced } \\
\text { or metastatic NTRK gene fusion solid tumors, no acquired resistance mutation, have progressed } \\
\text { following treatment or have no satisfactory alternative therapy, available }\end{array}$ & \\
\hline
\end{tabular}

well as for ROS1-positive advanced NSCLC (Table 3). In an integrated analysis of 3 phase I/II trials, entrectinib demonstrated 50\% ORR in patients with NTRK fusion-positive solid tumors and $70 \%$ in ROS1positive NSCLC patients. The intracranial ORR was $55 \%$ in both ROS1-positive NSCLC patients and NTRK fusion-positive solid tumor patients. The median duration of response ranged from 12.6 to 24.6 months [36, 37].

DS-6051b is a TKI with high affinity for ROS1 and NTRK kinases/In a phase I/Ib trial, it was found to be well tolerated and had a signal of inhibitory activity. Six patients were evaluated for efficacy, Two had PR and 2 had stable disease (SD) [38].

Repotrectinib (TPX-0005) is a potent next-generation ALK, ROS1, or NTRK1-3 fusion TKI. It is greater than 90-fold more potent than crizotinib. Repotrectinib demonstrates overall and intracranial anti-tumor activity in ROS1 positive advanced NSCLC patients.

In a phase I trial, 65 patients who had either ALK+, ROS1+, or NTRK+ advanced solid tumors were included, 23 patients had baseline CNS disease. The most common TEAEs were dysgeusia, dizziness, paresthesia, and nausea. DLTs occurred in 2 NSCLC patients at 240 mg daily and $160 \mathrm{mg}$ daily dose. MTD has not been reached. Confirmed partial response was observed in 8 patients with ROS1+/NTRK+. For ALK + patients, 4/16 had stable disease [39]. In the updated report, 75 patients were enrolled. Twenty-eight patients were ROS1+. The ORR was $90 \%$ in 10 TKI-naïve patients and $28 \%$ in 18 TKI pre-treated patients. The response rate was $44 \%$ in 9 TKI pre-treated patients who received a repotrectinib dose of $160 \mathrm{mg}$ or above. The intracranial ORR was $100 \%$ in 3 TKI naïve patients and $50 \%$ in 4 TKI pretreated patients [40].

\section{BRAF V600E mutations}

An activating BRAF mutation occurs in $1-3 \%$ of NSCLC patients with a related history of smoking. The combination of dabrafenib and trametinib was approved for the treatment of metastatic NSCLC harboring BRAF V600 E mutations based on an open-label trial. A total of 93 patients were enrolled in the trial. Fifty-seven of the 93 patients received previous systemic treatment and 36 patients were treatment naïve. All patients received dabrafenib $150 \mathrm{mg}$ oral twice daily and trametinib $2 \mathrm{mg}$ orally once a day. The ORR was $63 \%$ in pretreated patients and a response duration of $\geq 6$ months was observed in $64 \%$ of responders. In treatment-naïve patients, the ORR was $61 \%$ and the response duration of $\geq 6$ months was observed in $59 \%$ of responders (Table 4) [41, 42].

\section{MET inhibitors}

MET is tyrosine kinase receptor binding with hepatocyte growth factor (HGF). MET gene amplification and exon14-skipping mutations are characteristic abnormalities causing increased MET signaling activation. Isolated MET exon 14 mutation is found in 3\% of NSCLC; however, it is an acquired EGFR TKI resistance pathway in 15-20\% of EGFR mutation-positive NSCLC cases [43]. Crizotinib and cabozantinib have been shown to have some activity against MET $[44,45]$.

Capmatinib is a highly selective MET inhibitor. In a phase II trial, Capmatinib was given to advanced NSCLC patients with MET exon-14-skipping mutations or MET amplifications. Ninety-seven MET exon-14 NSCLC patients were evaluable for efficacy. The ORR was $39.1 \%$ in pretreated patients and $71.4 \%$ in treatment-naïve patients. The most common adverse events were peripheral edema, nausea, and vomiting [46].

Tepotinib is another highly selective MET inhibitor. In a phase II trial, tepotinib single agent was given as firstline to advanced NSCLC patients with MET exon 14 mutations identified through liquid biopsy or tumor biopsy. Eighty-five patients were enrolled and 76 patients were evaluable for efficacy. The ORR was $51.4 \%$ in liquid biopsy patients and $41.5 \%$ tumor biopsy patients. The most common TEAEs were peripheral edema, diarrhea, nausea, and asthenia. TEAEs lead to discontinuation in 2 patients, one due to interstitial lung disease and another one due to nausea and diarrhea [47].

\section{RET fusion/rearrangement inhibitors}

RET gene encodes a receptor tyrosine kinase (RTK) belonging to the RET family of RTKs. RET rearrangements are found in 1-2\% lung adenocarcinoma and are 
Table 4 FDA-approved targeted therapy for BRAF mutations

\begin{tabular}{llll}
\hline Drug & Month/year & Indication & Comments \\
\hline Dabrafenib+trametinib & June/2017 & Metastatic BRAF V600E+ NSCLC & \\
\hline
\end{tabular}

mutually exclusive with mutations involving EGFR, ALK, ROS1, BRAF, or KRAS.

The most common fusion partner for RET rearrangements in patients with NSCLC is KIF5B.

Multi-targeted TKIs (MKIs) such as cabozantinib, vandetanib, lenvatinib, sunitinib, and target RET fusiondriven NSCLCs have been tested. The most studied RET inhibitors are cabozantinib and vandetanib, which both showed a response rate between 20 to $50 \%$ in patients with RET-rearranged NSCLC [48-50]. Lenvatinib and sunitinib have been used in fewer patients with reported response rate at $16-22 \%[51,52]$. These agents are approved for other indications but are not designed to selectively target RET. Given the low response rate to Multi-targeted TKIs in RET-rearranged NSCLC, the next-generation RET-selective inhibitors, RXDX-105, BLU-667, and LOXO-292, are being tested.

RXDX-105 is a VEGFR-sparing potent RET inhibitor. In a phase Ib study, 21 untreated RET fusion-positive NSCLC patients received RXDX-105. Of these, eight patients harbored non-KIF5B-RET fusions and six out eight patients (75\%) achieved response. None of the 13 patients with KIF5B-RET fusions had a RECIST response [53].

BLU-667 demonstrated $\geq 10$-fold increase in potency over the FDA-approved MKIs, against oncogenic RET rearrangements. In a phase I study, seven out of 14 (50\%) RET fusion NSCLC patients who received BLU667 achieved objective response [54].

In an updated report, 79 advanced RET fusion+ NSCLC patients received BLU-667. The ORR was 56\% in 57 evaluable patients. The DCR was $91 \%$. Six patients had response duration $\geq 6$ months. The Most commonly reported TEAEs are increased AST, hypertension, increased ALT, constipation, fatigue, and decreased neutrophils [55].

LOXO-292 is another RET-selective TKI. A phase I basket trial of LOXO-292 in RET-driven cancers was presented at the American Society of Clinical Oncology Annual Meeting in 2018. Fifty-seven patients were treated with LOXO-292. Twenty-seven of the 57 were patients with NSCLC. The ORR in evaluable RET fusion-positive patients was $69 \%(22 / 32)$ and $65 \%$ (17/ 26 ) in NSCLC. The median duration of response has not been achieved but is estimated to be greater than 6 months [56].

RXDX-105, BLU- 667, and LOXO-292 also demonstrated some central nervous system penetration in these early-phase trials.

\section{HER2}

Human epidermal growth factor receptor 2 (HER2; ERBB2) is a member of the tyrosine kinase receptor family, which also includes HER1, HER3, and HER4.

HER2-targeted therapy has showed improved survival in breast cancer and gastroesophageal cancers. In the Lung Cancer Mutation Consortium (LCMC), HER2 mutations account for about $3 \%$ of patients with lung adenocarcinoma [57].

In a single-arm phase II study, trastuzumab-paclitaxel showed anti-tumor activity with an ORR of $46 \%(11 / 24)$ of EGFR TKI pretreated patients with an activating EGFR mutation and HER2 mutation.

Recently, a phase II basket trial evaluated adotrastuzumab emtansine for patients with HER2-mutant lung adenocarcinomas. Eight out of 18 patients (44\%) responded. The median PFS was 5 months [58].

Trastuzumab deruxtecan (DS-8201a) is a HER2targeting antibody-drug conjugate with a topoisomerase I inhibitor. In December 2019, trastuzumab deruxtecan was approved by FDA for patients with unresectable or metastatic HER-2 breast cancer who have received two or more prior anti-HER2-based treatments. In a large phase 1 trial, it also showed efficacy in HER-2 expression solid tumors other than breast cancer or gastric cancer. ORR was $36.4 \%(8 / 22)$ and DCR was $81.8 \%(18 / 22)$. Median duration of response and median PFS were not reached. Common TEAEs were nausea, vomiting, and decreased appetite $[59,60]$.

In an international multicenter retrospective study, 27 patients with stage IV or recurrent HER2-mutated NSCLC were treated with afatinib. The ORR was $13 \%$ (3/23 evaluable patients) and the median overall survival from the date of diagnosis of metastatic or recurrent disease was 23 months [61].

In a phase II trial of dacomitinib in patients with HER2-mutant or amplified tumors, partial response was observed in 3 of 26 patients with HER2 exon 20 mutations and no response was observed in 4 patients with HER2 amplifications. The median overall survival was 9 months from start of dacomitinib for patients with HER2 mutations.

XMT-1522, a novel HER2-antibiody-drug conjugate, is an auristatin-derivative conjugated to a novel anti-HER2 (Dolaflexin). A phase 1 trial showed that the drug conjugate is well tolerated up to $21.3 \mathrm{mg} / \mathrm{m} 2$, and showed early signs of anti-tumor activity. The DCR was $5 / 6$ (83\%) for patients dosed at 16 or $21.3 \mathrm{mg} / \mathrm{m} 2$ with $1 \mathrm{PR}$ and 4 SD [62]. 
Pyrotinib is an oral pan-TKI that inhibits HER1, HER2, and HER4. In a phase II trial, 60 patients with advanced NSCLC with HER2 exon 20 mutations who had disease progression after platinum-based chemotherapy were enrolled to receive pyrotinib $400 \mathrm{mg}$ once daily. The ORR was $31.7 \%$ and the median duration of response was 7.0 months. The median PFS was 6.8 months. Grade 3 TEAEs occurred in about $26.7 \%$ patients $[63,64]$.

As previously mentioned, 13 patients were enrolled to HER2 cohort of poziotinib phase II clinical trial and 12 patients were evaluated for response. The ORR is 50\% and the DCR is $83 \%$.

\section{KRAS G12C inhibitor}

KRAS mutations represent one of the most common oncologic driver mutations in advanced NSCLC. The KRAS G12C mutation accounts for about $14 \%$ of lung adenocarcinoma. Patients with KRAS + NSCLC have a shorter median survival. Until recently, no effective treatment against KRAS has been identified.

AMG510 is a small promising molecule that selectively inhibits KRAS G12C by locking it in an inactive GDPbound state. A phase 1 study evaluated AMG 510 in adult patients with locally advanced or metastatic KRAS G12C mutation solid tumors. Thirteen NSCLC patients were enrolled to the study. These patients have a median of 3 lines of previous treatments. Ten patients were evaluated for efficacy. Five had a PR with ORR about 50\%, 4 had SD and 1 had PD. Six NSCLC patients reported 10 TEAEs (6 grade 1,2 grade 2 , and 2 grade 3 ). The grade 3 TEAEs were anemia and diarrhea. The most common AEs were decreased appetite and diarrhea $[65,66]$.

MRTX849 is another KRAS G12C inhibitor showing activity in treating advanced solid malignancies with KRAS G12c mutations. In a phase I/II study, 17 patients received MRtx849 with dose ranged from $150 \mathrm{mg}$ to $1200 \mathrm{mg}$ daily. Of 10 NSCLC patients treated, 6 patients were evaluable and 3 achieved PR with ORR about $50 \%$. Common TEAEs were diarrhea, nausea, vomiting, elevated liver enzymes, increased creatinine, and decreased appetite. Grade 3 toxicities were fatigue, decreased appetite, and dyspnea [67].

Single-agent and combination studies are ongoing for AMG510 and MRTX849.

\section{ATR inhibitor}

ATR is a critical component in DNA damage response and inhibition of ATR signaling may sensitize tumors to DNA-damaging chemotherapy. M6620 is a selective inhibitor of ATR. M6620 monotherapy is well tolerated but showed limited anti-tumor activity. Thirty-three patients with advanced NSCLC who had received up to 2 lines of prior therapies were enrolled in a phase I trial of
M6620 plus gemcitabine. Grade 3 or higher TEAEs occurred in 19/33 (57.6\%) patients and the most commonly reported TEAEs were fatigue, neutropenia, anemia, and thrombocytopenia. Efficacy was evaluable in 24 patients. The ORR was $12.5 \%$ and 18 patients had SD [68].

\section{AXL kinase inhibitor}

AXL overexpression may induce epithelial to mesenchymal transition, tumor angiogenesis, resistance to chemotherapeutic and targeted agents, and decreased anti-tumor immune response. Inhibition of AXL by TP0903 may potentially reduce cancer cell metastasis, reverse resistance to immunotherapy and targeted therapy, and activate the anti-cancer immune response.

A phase Ia/Ib study to evaluate safety and PK/PD of TP-0903, a potent inhibitor of AXL kinase in advanced solid tumors is ongoing. Results are not yet available [69].

Bemcentinib is an oral highly selective inhibitor of the AXL tyrosine kinase. Thirty-eight advanced NSCLC patients who had progressed on one line of platinumbased chemotherapy or first-line of targeted therapy of EGFR inhibitor or ALK inhibitor were enrolled in a phase II trial of bemcentinib in combination with pembrolizumab. The most common TEAEs were transaminase increases, diarrhea, and asthenia. Efficacy was evaluable in 29 patients. The ORR was $24 \%$. For AXL-positive patients, the ORR was $40 \%$. The median PFS was 4.0 months and 5.9 months for AXL-positive patients [70].

In a phase I/II clinical trial, bemcentinib and docetaxel combination was given to patients with previously treated non-squamous NSCLC. Eleven patients were treated. Two DLTs were observed in a dose of $75 \mathrm{mg} /$ $\mathrm{m} 2$ docetaxel and $100 \mathrm{mg}$ daily of bemcentinib; thus, the ongoing recruitment was continued with a dose of 60 $\mathrm{mg} / \mathrm{m} 2$ docetaxel and $100 \mathrm{mg}$ daily of bemcentinib. Efficacy was evaluable in 7 patients, 2 achieved PR and 2 had SD [71].

\section{VEGF/VEGEFR}

MP0250 is a tri-specific DARP in compound neutralizing VEGF-A and HGF as well as binding albumin and increasing plasma half-life. A phase I trial of MP0250 resulted in a MTD of $8 \mathrm{mg} / \mathrm{kg}$ and was well tolerated. Two patients had PR, which indicated signs of anti-tumor activity [72].

Figure 1 briefly summarized the emerging targeted therapy discussed above.

\section{Antibody-drug conjugates}

JNJ-372 is an EGFR-cMet bispecific antibody that showed activity in EGFRm NSCLC. In a phase 1 study, advanced EGFRm NSCLC patients, including patients 


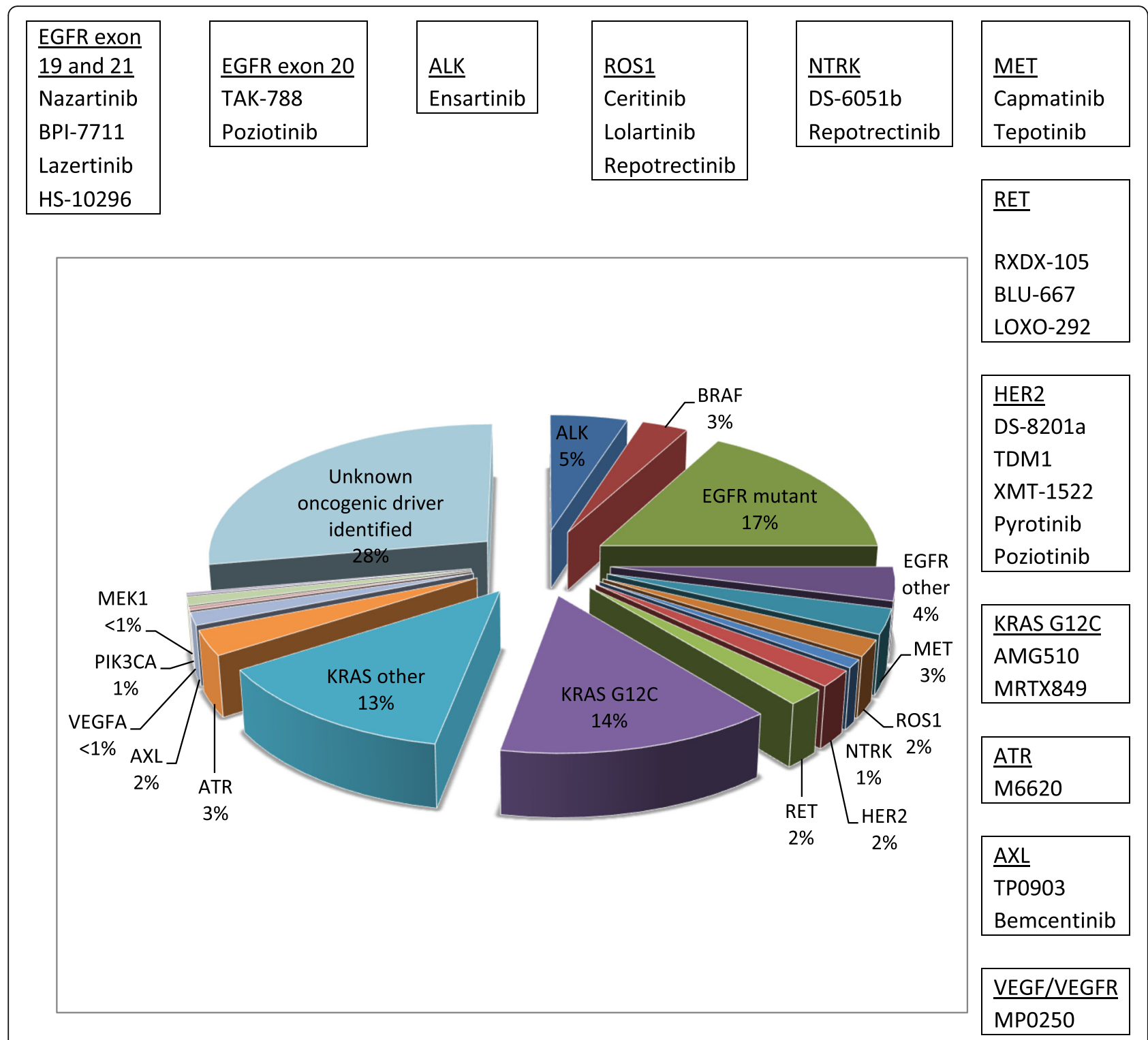

Fig. 1 Mutation frequency of lung adenocarcinoma and emerging drugs targeted these mutations. Frequency data is a combination from the AACR GENIE data and Lung Cancer Mutation Consortium [73, 74]

who have progressed on 3rd generation EGFR TKI and EGFR Exon 20 disease, were enrolled. Of 116 treated NSCLC patients, common adverse events were rash, infusion-related reaction, paronychia, and constipation. Efficacy was evaluated in 88 patients. The ORR was $28 \%$. PR was observed in $10 / 47$ patients with prior 3rdgeneration EGFR TKI. PR was observed in $6 / 20$ patients with EXON 20 [75].

DS-1062a is an antibody-drug conjugate that is comprised of trophoblast cell-surface antigen 2 (TROP2)-targeting antibody attached to topoisomerase I inhibitor payload by a tetrapeptide-based linker. Overexpression of TROP2 may be related to poor survival in solid tumor patients. A phase I study of DS-1062a in patients with advanced solid tumors is ongoing. Twenty-two patients with advanced NSCLC received treatment of DS-1062a at doses of $0.27-2.0 \mathrm{mg} / \mathrm{kg}$. Median of 2 cycles was initiated. Grade 1 TEAEs were experienced in $81.8 \%$ of patients. Fatigue was the most commonly reported TEAE and was the only grade 3 TEAE. Efficacy was evaluated in 18 patients, 1 achieved PR and 8 achieved SD [76].

EnaV is anti-AXL humanized IgG1 conjugated with monomethyl auristatin E. In a phase I/II clinical trial, heavily pretreated solid tumor patients with relapsed or refractory disease were enrolled to received monotherapy of EnaV. The recommended phase II dose was 2.2 $\mathrm{mg} / \mathrm{kg}$ once every 3 weeks. Twenty-six advanced NSCLC patients who are EGFR and ALK wide type and failed $\leq$ 
4 lines of systemic therapies including platinum-based chemotherapy and PD-1/PD-L1 inhibitor were enrolled. Nine out 12 evaluable fresh biopsies were AXL-positive. The ORR is $19 \%$ and DCR is $50 \%$. The most common grade 3 or 4 TEAEs were gastrointestinal disorders, nausea, vomiting, and diarrhea [77].

An antibody-drug conjugate PF-06647020 (PF-7020) targeting PTK7 (protein tyrosine kinase 7) was evaluated in a phase I trial, in advanced solid malignancies; the antibody-drug conjugate results indicate a manageable safety profile and promising activity. Four of 23 NSCLC patients had PR; 10/23 had SD [78].

Anetumab ravtansine is a human anti-mesothelin IgG1 antibody conjugated to the maytansinoid tubulin inhibitor DM4. A phase 1b study of anetumab ravtansine in patients with mesothelin-expressing advanced or recurrent malignancies is ongoing and results are not yet available [79].

BA3011 is an anti-AXL humanized monoclonal antibody conjugated to monomethyl auristatin $\mathrm{E}$ using a cleavable linker (CAB-AXL-ADC). Preclinical data showed BA3011 has anti-tumor activity in NSCLC, pancreatic, castration-resistant prostate cancer (CRPC), and other tumor models. A phase I study of BA3011 in patients with advanced solid tumors is ongoing and results are not yet available [80].

BT1718 is a bicycle drug conjugate comprising a bicyclic peptide that binds membrane type I matrix metalloproteinase (MT1-MMP) and is linked to maytansinoid tubulin inhibitor DM1 by a cleavable disulfide linker. MT1-MMP overexpression was seen in NSCLC. A phase I/IIa trial of BT1718 in patients with advanced solid tumors is ongoing and results not yet available [81].

High expression of HER3/ERBB3 in NSCLC may be correlated with poorer outcomes. U3-1402 is a HER3targeting antibody-drug conjugate (ADC), composed of patritumab monocloncal antibody directed against HER3 linked to the topoisomerase I inhibitor DX8951. A current phase I clinical trial of U3-1402 in metastatic or unresectable adenocarcinoma NSCLC subjects harboring EGFR-activating mutation who (a) are T790M mutationnegative after disease progression during treatment with erlotinib, gefitinib, or afatinib or (b) develop disease progression while on osimertinib. Results are not yet available [82].

\section{Immunotherapy}

Cancer immunotherapy therapy works by empowering our own immune system to fight against cancer. It is a rapidly advancing and an important force in the fight against cancer along with surgery, radiation, chemotherapy, targeted therapy, and endocrine therapy.

Immunotherapy can be activated through vaccine therapies to stimulate the immune system to attack cancer cells (active immunotherapy) or through checkpoint inhibitors to remove the immune blockage (passive immunotherapy).

Using our own immune system to treat cancer was first noted in the nineteenth century by Dr. William Coley. Dr. Coley observed some cancer patients went into spontaneous remission after erysipelas infection. He began injecting mixtures of live and inactivated bacteria (Coley's mixed bacterial toxin) into patients' tumors in 1891. Coley reported a significant number of patients with cancer achieved response and cure. Today Dr. Coley is known as the Father of immunotherapy. His method gained acceptance but then gradually disappeared with the development of radiation and chemotherapy as well as the risk associated with infecting cancer patients with bacteria [83].

Another early cancer immunotherapy, Bacillus Calmette-Guérin (BCG) was used in the treatment of superficial bladder cancer. First reported by Dr. Old, BCG was used as a treatment in a mice model in 1959. Dr. Old is now known as Father of Modern Tumor Immunology. Thomas and Burnet proposed the theory of immunosurveillance. In 1957, they hypothesized that lymphocytes act as sentinels in recognizing and eliminating continuously arising, nascent transformed cells [84, 85].

The first approved immunotherapy in metastatic NSCLC was nivolumab. Nivolumab is a fully human IgG4 PD-1 immune-checkpoint-inhibitor antibody. It binds to PD-1 receptor this block tumor PD-L1 to bind with T cell PD-1 receptor thus restores anti-tumor immunity. In CheckMate 017, a phase III clinical trial, patients with metastatic squamous cell NSCLC who had disease progression after platinum-based chemotherapy were randomized to receive nivolumab or docetaxel. The median OS was significantly improved for nivolumab (9.2 vs 6.0 months), as well as response rate (20\% vs $9 \%)$ and median PFS (3.5 vs 2.8 months) [86].

Table 5 shows FDA-approved immunotherapies. Both nivolumab and pembrolizumab are PD-1 immunecheckpoint-inhibitor antibodies. Atezolizumab is a fully humanized IgG1 antibody against PD-L1.

Pembrolizumab has been FDA-approved in metastatic NSCLC second-line setting if PD-L1 tumor proportion score (TPS) $>1 \%$. It was also approved in first-line metastatic NSCLC with PD-L1 TPS > 50\% after a phase 3 trial showed significantly longer progression-free survival and overall survival and less side effects when compared with platinum-based chemotherapy. In the KEYNOTE-042 study, pembrolizumab monotherapy was compared with platinum-based chemotherapy in first-line therapy for advanced/metastatic NSCLC with PD-L1 TPS $\geq 1 \%$. Pembrolizumab significantly improved OS in patients 
Table 5 FDA-approved immunotherapy in advanced/metastatic NSCLC

\begin{tabular}{|c|c|c|c|}
\hline Drug & Class & Month/year & Indication(s) \\
\hline \multirow{2}{*}{$\begin{array}{l}\text { Nivolumab } \\
\text { (OPDIVO) }\end{array}$} & \multirow[t]{2}{*}{ Anti-PD-1 } & March/2015 & Metastatic squamous NSCLC with progression on or after platinum-based chemotherapy. \\
\hline & & October/2015 & $\begin{array}{l}\text { Metastatic NSCLC in patients with progression on or after platinum-based chemotherapy. } \\
\text { Patients with EGFR or ALK genomic tumor aberrations should have disease progression } \\
\text { on FDA-approved therapy for these aberrations prior to receiving OPDIVO. }\end{array}$ \\
\hline \multirow[t]{5}{*}{$\begin{array}{l}\text { Pembrolizumab } \\
\text { (KEYTRUDA) }\end{array}$} & \multirow[t]{5}{*}{ Anti-PD1 } & October/2015 & $\begin{array}{l}\text { Metastatic NSCLC whose tumors express PD-L1 (TPS } \geq 1 \% \text { ) with progression or after } \\
\text { platinum-containing chemotherapy. Patients with EGFR or ALK genomic tumor aberrations } \\
\text { should have disease progression on FDA-approved therapy for these aberrations prior to } \\
\text { receiving KEYTRUDA. }\end{array}$ \\
\hline & & October/2016 & $\begin{array}{l}\text { NSCLC whose tumors have high PD-L1 expression (TPS } \geq 50 \% \text { ), with no EGFR or ALK } \\
\text { genomic tumor aberrations, and no prior systemic chemotherapy treatment for metastatic } \\
\text { NSCLC. }\end{array}$ \\
\hline & & May/2017 & $\begin{array}{l}\text { In combination with pemetrexed and carboplatin, as first-line treatment of patients with } \\
\text { metastatic non-squamous NSCLC and with no EGFR or ALK genomic tumor aberrations. }\end{array}$ \\
\hline & & October/2018 & $\begin{array}{l}\text { In combination with carboplatin and either paclitaxel or nabpaclitaxel, as first-line treatment } \\
\text { of patients with metastatic squamous NSCLC. }\end{array}$ \\
\hline & & April/2019 & $\begin{array}{l}\text { Single agent for the first-line treatment of patients with stage III NSCLC, who are not } \\
\text { candidates for surgical resection or definitive chemoradiation, or metastatic NSCLC, and } \\
\text { whose tumors expresS PD-L1 [tumor proportion score (TPS) } \geq 1 \% \text { as determined by an } \\
\text { FDA-approved test, with no EGFR or ALK genomic tumor aberrations. }\end{array}$ \\
\hline \multirow[t]{3}{*}{$\begin{array}{l}\text { Atezolizumab } \\
\text { (TECENTRIQ) }\end{array}$} & \multirow[t]{3}{*}{ Anti-PD-L1 } & October/2016 & $\begin{array}{l}\text { Metastatic NSCLC who have disease progression during or following platinum-containing } \\
\text { chemotherapy. Patients with EGFR or ALK genomic tumor aberrations should have disease } \\
\text { progression on FDA-approved therapy for these aberrations prior to receiving TECENTRIQ. }\end{array}$ \\
\hline & & December/2018 & $\begin{array}{l}\text { In combination with bevacizumab, paclitaxel, and carboplatin, for the first-line treatment } \\
\text { of adult patients with metastatic non-squamous NSCLC with no EGFR or ALK genomic } \\
\text { tumor aberrations. }\end{array}$ \\
\hline & & December/2019 & $\begin{array}{l}\text { In combination with paclitaxel protein-bound and carboplatin for the first-line treatment } \\
\text { of adult patients with metastatic non-squamous non-small cell lung cancer (NSCLC) with } \\
\text { no EGFR or ALK genomic tumor aberrations. }\end{array}$ \\
\hline
\end{tabular}

TPS tumor proportion score

with TPS $\geq 50 \%$ (20 months vs 12.2 months, HR 0.69 ), TPS $\geq 20 \%$ (17.7 months vs 13 months, HR 0.77 ), and TPS $\geq 1 \%$ (16.7 months vs 12.1 months, HR 0.81) [87].

More recently, pembrolizumab in combination with chemotherapy showed an improved OS irrespective of PD-L1 status when compared to chemotherapy. The benefits can be seen in both non-squamous and squamous histology type. In non-squamous, the hazard ratio for death is 0.49 and the 12-month overall survival is $69.2 \%$. In squamous, the hazard ratio for death is 0.64 with a median overall survival of 15.9 months in pembrolizumab-chemotherapy combination group compare to chemotherapy group.

Recently, atezolizumab in combination with bevacizumab, paclitaxel, and carboplatin was approved for the first-line treatment of adult patients with metastatic non-squamous NSCLC with no EGFR or ALK genomic tumor aberrations. In a phase 3 randomized trial, atezolizumab (A) in combination with bevacizumab, paclitaxel, and carboplatin (BCP) showed longer median PFS (8.3 months) than the BCP group (6.8 months). The Hazard ratio for disease progression or death is 0.62 with 95\% confidence interval 0.52 to 0.74 [88].

\section{Anti-PD1/PD-L1 and anti-CTLA-4}

In a phase III trial, first-line treatment with nivolumab plus ipilimumab in advanced NSCLC showed improved overall survival compare with patients treated with chemotherapy, regardless of PD-L1 expression. For patients treated with nivolumab+ipilimumab, median OS was 17.1 months (PD-L1 expression $>1 \%$ ) and 17.2 months (PD-L1 < 1 ) compare to 14.9 months (PD-L1 > $1 \%)$ and 12.2 months (PD-L1 $<1 \%$ ) in patients treated with chemotherapy [89].

A phase 1A/1B study (NCT02407990) showed singleagent tislelizumab (anti-PD-1) was well tolerated and showed evidence of anti-tumor activity in patients with solid tumors, including NSCLC. In a phase II trial, tislelizumab in combination with chemotherapy was evaluated as a first-line treatment in Chinese patients with advanced NSCLC. Fifty-four patients were enrolled in the study. The ORR was $67 \%$ (36/54). Grade 3/4 AEs occurred in $>15 \%$ patients. The most commonly reported AEs were decreased neutrophil counts and anemia [90].

Cemiplimab is a human monoclonal anti-PD-1 and was approved for advanced and metastatic cutaneous squamous cell carcinoma not suitable for curative surgery or radiation. In a phase II trial, cemiplimab was 
evaluated in advanced NSCLC patients who were refractory or have progressed to at least first-line therapy. Twenty-one patients were enrolled. Grade 3 TEAEs occurred, including pneumonitis, diabetic ketoacidosis, and nephritis. The ORR was $28.6 \%(6 / 21)$ and DCR was $57.1 \%(12 / 21)$ [91]. A phase I study to evaluate a combination of cemiplimab plus REGN4659 (anti-CTLA-4) in advanced or metastatic NSCLC patient is ongoing, results not available yet.

JS001 is a humanized IgG4 anti-PD-1 antibody. In a phase I study, JS001 monotherapy was evaluated in patients with advanced or recurrent malignancies. Thirtythree patients were enrolled and the results indicate that it is well tolerated. No DLT was reported. Most TEAEs were grade $1-2$. The ORR was $48.5 \%$ (16/33) and DCR was 70\% (28/33). Two NSCLC patients achieved PR [92].

In a phase I/II study, spartalizumab (PDR001), an antiPD1 monoclonal antibody was shown to have efficacy in advanced melanoma and NSCLC. The ORR was 9\% (11/ 118) in NSCLC patients [93]. PDR001 in combination with platinum-doublet was evaluated in PD-L1 metastatic NSCLC patients; results are not yet available [94].

Camrelizumab (SHR-1210) is another PD-L1 monoclonal antibody. It is approved in China for the treatment of relapsed or refractory classical Hodgkin lymphoma. In a phase I/II study, camrelizumab plus apatinib was evaluated in advanced NSCLC patients for second-line treatment. Ninety-six patients with nonsquamous NSCLC and wide type for EGFR and ALK were enrolled. Efficacy was evaluated in 91 patients. The ORR was $29.7 \%$ and DCR was $81.3 \%$. Grade 3 and 4 TEAEs occurred in $56.2 \%$ of patients and the most commonly reported AEs were hypertension, hand-foot syndrome, proteinuria, gamma-glutamyl transferase increase, abnormal hepatic function, and alkaline phosphatase increase [95].

\section{Siglec-15 antibody}

Siglec-15 is an immunoglobulin-like protein that can be upregulated in many human cancers. Siglec-15 expression works as a critical immune suppressor and is mutually exclusive to PD-L1.

NC 318 is a monoclonal antibody targeting Siglec- 15 to normalize immune system. In a phase I study, 13 NSCLC patients who had prior treatments and PD-L1 refractory were enrolled and received NC 318 at different doses. Two patients achieved response with one CR and one PR. NC 318 was safe and well tolerated in 49 patients with advanced solid tumors. The dose-limiting toxicity was a grade 3 pneumonitis in the $1600 \mathrm{mg}$ cohort [96].

\section{T cell therapy}

MAGE-A10 is expressed in 10-50\% of NSCLC, urothelial, melanoma, and head and neck cancer. Affinity- enhanced autologous MAGE-A10 ${ }^{\mathrm{c} 796} \mathrm{~T}$ cells were evaluated in patients with these advanced cancers that had progressed after at least one line of therapy. In a phase 1 trial, these first-in-human $\mathrm{T}$ cells were given at $0.1 \times 10^{9}$ to 8 patients. Grade $3 \mathrm{AEs}$ were observed in 2 patients including pancytopenia and hyponatremia. One DLT of cytokine release syndrome was observed. No efficacy data is available yet [97].

\section{Autologous tumor-infiltrating lymphocytes}

Tumor-infiltrating lymphocyte (TIL) therapies are a form of adoptive cell transfer (ACT) immunotherapy which has showed durable response in tumors with high mutation burdens. LN-144/LN-145 is a preparation of TIL extracted from surgically resected tumors, followed by culture with IL-2. LN-144/LN-145 is then infused back to the patient. A phase 2 study is ongoing to assess the efficacy and safety of LN$144 / \mathrm{LN}-145$ alone and in combination with pembrolizumab in patients with advanced or metastatic solid tumors. One of the cohorts is for NSCLC patients who have received up 3 lines of prior therapy. No results are available yet. LN-144 reported to achieve $38 \%(21 / 55)$ ORR in metastatic melanoma patients who had 3.1 mean prior therapies. LN-145 induced $44 \%(12 / 27)$ ORR in patients with advanced cervical cancer who had at least 1 prior line of chemotherapy (NCT03645928) [98, 99].

\section{Adenosine 2a receptor $\left(A_{2 a} R\right)$ antagonist}

Adenosine signaling through $\mathrm{A} 2 \mathrm{a}$ receptor on immune cells may have immunosuppressive effects. NIR178 is an oral $A_{2 \mathrm{a}} R$ antagonist that selectively inhibits $A_{2 \mathrm{a}} R$ and may reactivate $T$ cell-mediated anti-tumor immune response. A phase I/II study evaluated NIR178 in pretreated NSCLC patients. Twenty-four patients were enrolled in the study. The most commonly reported AEs were nausea, fatigue, dyspnea, vomiting, and chest pain. Grade 3 drug-related AEs reported include pneumonitis (8\%) and nausea (4\%). No grade 4 AEs were reported. Efficacy was evaluated in 17 patients. One had CR, 1 PR, and 2 SD [100].

AB928 is a selective $A_{2 a} R / A_{2 b} R$ antagonist. $A B 928$ was evaluated in a phase 1 trial in combination with chemotherapy or AB122 (anti-PD-1) in patients with advanced tumors.

Nine patients were enrolled and six patients received AB928 and AB122. AB928 combination therapy was well tolerated. There were two evaluable patients and both had SD [101].

A phase I study to evaluate PBF-1129 (A2aR antagonist) in metastatic NSCLC is ongoing, results not yet available (NCT03274479). 


\section{Anti-IL-8 monoclonal antibody}

Interleukin 8 (IL-8) has been suggested to promote immune escape. BMS-986253 is a human monoclonal antibody that binds and inhibits IL-8. A phase I trial showed BMS-986253 monotherapy in metastatic or unresectable solid tumors was well tolerated in 15 patients and MTD was not reached at $32 \mathrm{mg} / \mathrm{kg}$. TEAEs occurred in 5 patients and most were grade 1 with the exception of grade 2 fatigue, hypophosphatemia, and hypersomnia in 2 patients. Eleven (73\%) patients achieved SD [102].

High levels of serum IL-8 are associated with poor outcome in NSCLC and decreases of IL- 8 may be associated with response in NSCLC patients treated with nivolumab. A phase $1 \mathrm{~b} / 2$ study of nivolumab in combination with BMS-986253, in a biomarker-enriched population of patients with advanced cancer is ongoing; results are not yet available [103].

\section{CD40 agonist}

CD40 is an immune-activating TNF receptor. APX005M is a humanized monoclonal antibody binds to CD40 and activates antigen-presenting cells leading to stimulation of cancer-specific $\mathrm{T}$ cell responses.

In a phase I/II trial, APX005M plus nivolumab was evaluated in metastatic melanoma or NSCLC patients. One of 4 NSCLC immunotherapy naïve patients, had confirmed CR and 2 had SD [104].

SEA-CD40 is a non-fucosylated CD40 agonist that was evaluated in a phase I study in relapsed/refractory metastatic solid tumors. Forty-eight patients enrolled in the study and SEA-CD40 monotherapy was found to have a tolerable safety profile. DLT (infusion-related reactions) occurred in 5 patients. Common TEAEs were infusionrelated reactions, chills, fatigue, nausea, vomiting, dyspnea, and headache. Efficacy was evaluated in 32 patients 1 had PR (basal cell carcinoma) and 10 had SD with DCR 32\% [105].

\section{CD122-biased agonist}

NKTR-214 is a CD122 biased agonist. It binds to CD122, a subunit of IL-2 receptor on T and NK cells. NKTR-214 promotes the activation and proliferation of $\mathrm{CD}^{+} \mathrm{T}$ cells and NK cells. It also increases expression of PD-1 protein on T cells and PD-L1 on cancer cells. Thus, NKTR-214 may have potential synergistic effects with anti-PD-1 or anti-PD-L1 inhibitors against cancer.

In a phase I/II (PIVOT) trial, NKTR plus nivolumab was evaluated in patients with advanced solid cancers. The ORR was $50 \%$ and DCR was $67 \%$ in 6 NSCLC patients. Commonly reported TEAEs included flu-like symptoms, fatigue, rash, and pruritus [106].

A phase I/II trial of NKTR-214 combined with pembrolizumab or atezolizumab in patients with advanced solid tumors is ongoing, and results are not yet available [107].

\section{Cytokine therapy}

ALT-803 is an IL-13 superagonist. In a phase I/II trial, ALT-803 was combined with nivolumab to treat patients with metastatic NSCLC. Among patients in phase Ib, who had PD1 immunotherapy relapsed or refractory tumors, the DCR was 91\% (10 of 11), 27\% (3 patients) had PR and 64\% (7 patients) had SD. In 10 patients with PD-L1 negative tumors, the DCR was $70 \%$ and $30 \%$ had PR [108].

\section{Indoleamine 2,3-dioxygenase (IDO) pathway}

Indoleamine 2,3-dehydrogenase (IDO) is an enzyme that catalyzes tryptophan into kynurenine. This enzyme is overexpressed in different malignancies. IDO causes depletion of tryptophan in the tumor microenvironment and tumor-draining lymph nodes thus inhibiting the function of immune effector cells.

IO102 is a second-generation immune-modulatory vaccine with a single IDO-derived peptide that activates CD8 T cells to kill IDO-expressing tumor cells and attacks immune suppressive cells. In a phase I study, the first generation IDO vaccine IO101 showed anti-tumor activity in pretreated advanced NSCLC. A phase I/II trial to evaluate IO102 in combination with pembrolizumab with or without chemotherapy as a first-line treatment in metastatic NSCLC patients is ongoing; results are not yet available $[109,110]$.

A phase I/II trial evaluated the IDO1 inhibitor, Epacadostat in combination with pembrolizumab in advanced NSCLC patients who have received platinum-based chemotherapy but no prior immunotherapy. Seventy patients were enrolled. The ORR was $29 \%(20 / 70)$ and the DCR was 50\% (35/70). Grade 3 and 4TEAEs were reported in $27 \%$ of patients [111].

\section{Leukemia inhibitory factor (LIF) monoclonal antibody}

LIF is expressed in multiple cancers and correlates with poor prognosis. Blocking LIF in mouse models has shown decreased tumor growth. A phase I study of MSC-1, a humanized anti-LIF monoclonal antibody in patients with advanced solid tumors is ongoing and results are not yet available [112].

\section{RORY agonist}

LYC-55716 is oral small-molecule agonist of retinoic acid receptor-related orphan receptor $\gamma(\mathrm{ROR} \gamma)$. In a preclinical model, ROR $\gamma$ agonist decreases expression of PD-1 and other co-inhibitory receptors. ROR $\gamma$ and PD1/PD-L1 inhibitors work synergistically. A phase $1 \mathrm{~b}$ trial to evaluate safety and efficacy of ROR $\gamma$ agonist LYC- 
55716 in combination with pembrolizumab in metastatic NSCLC is ongoing; results are not yet available [113].

\section{SIRPa-CD47 immune checkpoint blockade}

CD47 is expressed in all normal cells but overexpressed in tumor cells and it functions as an immune checkpoint in cancer. Signal-regulatory protein (SIRP) $\alpha$ is an inhibitory receptor expressed in myeloid cells. When CD47 in tumor cells binds to SIRPa in myeloid cells, it leads to suppression of tumor cell phagocytosis and other innate immune functions.

AXL148 is a fusion protein with high affinity for the CD47 binding domains in SIRP $\alpha$ that are linked to an inactive Fc region of human immunoglobulin. AXL148 has much higher affinity to bind to CD47 than the natural SIRP $\alpha$. In a phase I study, ALX148 in combination with pembrolizumab or trastuzumab was evaluated in patients with advanced malignancy with checkpoint inhibitor relapsed or refractory diseases. A total of 108 patients were enrolled. Fifty NSCLC patients received AXL148+pembrolizumab. Commonly reported TEAEs were fatigue, AST increase, ALT increase, anemia, and platelets decrease. Efficacy was evaluated in 23 patients; 1 had PR and 8 had SD with DCR 39.1\% [114].

\section{Anti-TIM-3 antibody and anti-LAG-3 antibody}

$\mathrm{T}$ cell immunoglobulin and mucin containing protein-3 (TIM-3) is another immune checkpoint expressed on CD8 $\mathrm{T}$ cells that could inhibit cancer immunity. Lymphocyte activation of gene-3 (LAG-3) is a coinhibitory receptor that is frequently co-expressed with PD-1 in tumor-infiltrating lymphocytes. LAG-3 is associated with impaired $\mathrm{T}$ cell function and with the combined inhibition of TIM3, PD-1, and LAG-3 may also increase anti-tumor activity and overcome the resistance to immunotherapy.

MK-4280 is a humanized immunoglobulin G4 antiLAG-3 antibody. In a phase I/II trial, MK-4280 in combination with pembrolizumab was evaluated in metastatic solid tumor patients who have failed the standard treatment. The ORR was $27 \%$ and DCR was $40 \%$ in 15 patients [115].

TSR-022 is a selective Anti-TIM-3 antibody. In the phase I/II AMBER study, TSR-022 was evaluated as monotherapy or in combination with TSR-042 (anti-PD1) and TSR-033 (anti-LGA-3) in advanced solid tumors. In the dose-expansion portion of the AMBER study, thirty-nine advanced NSCLC patients who had received prior anti-PD-1/PD-L1 treatment were enrolled to receive TSR-022 and TSR-042. Efficacy was evaluated in 20 patients who received TSR-022 at $300 \mathrm{mg}$ dose; 3 achieved PR and 8 had SD. ORR was 33.3\% (4/12) and DCR was $75 \%$ (9/12) in 12 PD-L1 $\geq 1 \%$ patients [116].
Eftilagimod alpha (Efti, IMP321) is a soluble LAG-3 fusion protein binds to major histocompatibility complex (MHC) class II and activates antigen-presenting cells. Efti has potential synergy with other therapeutic agents. In a phase II (TACTI-002) study, Efti plus pembrolizumab were given to 48 patients with metastatic NSCLC or head and neck carcinoma. TEAEs occurred in $>10 \%$ of patients and 2 TEAEs leading to treatment discontinuation: 1 with grade 4 hepatitis and another with grade 3 diarrhea. No new TEAEs. In part A of the study, 17 metastatic NSCLC patients received Efti+pembrolizumab as first-line treatment. ORR was $47 \%$ regardless of PD-L1 status. In part C of the study, ORR was 33\% (6/ 18) in metastatic head and neck patients second-line treatment [117].

\section{Single domain antibody conjugate}

L-DOS47 is a urease immune-conjugate. AFAFIKL2 (L) is a unique single domain antibody derived from liama antibody fragments. Urease (DOS47) is a microenvironment modifier and therapeutic agent. The AFFIKL2 antibody targets to deliver the enzyme and the urease enzyme convert urea into ammonia and increase the local $\mathrm{pH}$ level. In a phase I/II L-DOS47 monotherapy was evaluated for advanced non-squamous NSCLC patients, fifty-five patients were enrolled in sixteen cohorts. L-DOS47 monotherapy is well tolerated at dose levels up to $13.55 \mu \mathrm{g} / \mathrm{kg}$. No CR or PR reported. Efficacy was evaluable in 32 patients who had SD, 13 had a decrease in the sum of diameters of target lesions [118]. Phase I/ II studies to evaluate L-DOS47 in combination with cisplatin/vinorelbine (NCT03891173) in lung adenocarcinoma, and in combination with carboplatin/pemetrexed (NCT02309892) in recurrent or metastatic nonsquamous NSCLC are ongoing. Results are not yet available yet.

\section{Vaccines}

CV301 is a poxviral-based vaccine that could potentially increase the clinical benefit in combination with pembrolizumab. A phase 1 trial of CV301 has been completed and results indicate that there is no DLT. A phase $1 \mathrm{~b}$ trial to evaluate combination of CV301 and pembrolizumab in NSCLC patients is ongoing, results are not yet available [119].

Vaccine BI 1361849 (CV9202) has 6 mRNA encoding for selected tumor-associated antigens: MUC1, survivin, NY-ESO-1, 5 T4, MAGE-C2, and MAGE-C1. In a phase Ib study, BI 1361849 combined with local radiation were given to 26 stage IV NSCLC patients with progression of disease after standard first-line therapy. Common BI 1361849-related adverse events are injection site reactions and flu-like symptoms. The majority $(84 \%)$ of the patients have shown an increased BI 1361849 antigen- 
specific immune response. One patient had PR in combination with pemetrexed maintenance, and $46.2 \%$ had SD [120].

A phase I/II trial to evaluate BI 1361849 in combination with durvalumab or durvalumab + tremelimumab in patients with metastatic NSCLC is ongoing, results not available yet. This study combines active and passive immunotherapy [121].

Dendritic cell vaccine (DCVAC) can present tumor antigen to induce a durable immune response. In a phase II study, DCVAC in combination with standard chemotherapy was evaluated in metastatic NSCLC patients. When compared to chemotherapy alone, DCACV + chemotherapy improved the ORR (45\% vs $34 \%)$ and median OS (15.5 months vs 11.8 months) [122].

Universal cancer peptide-based vaccine (UCPVax) is a vaccine directed towards universal cancer peptide telomerase to activate CD4 helper T lymphocytes. A phase I/II trial to evaluate UCPVAx in patients with metastatic NSCLC is ongoing; results are not yet available (NCT02818426). DNA damage results in cancer neoantigens. Neoantigens may serve as targets for tumor-directed immune responses. The combination of immunotherapy and chemotherapy reduces early progression and may modulate the tumor microenvironment, which has been shown to improve survival over chemotherapy alone in patients with NSCLC. Neoantigen vaccines in combination with immunotherapy and chemotherapy may induce $\mathrm{T}$ cell reactivity and expand $\mathrm{T}$ cell response against neoantigens.

NEO-PV-01 is a personal neoantigen vaccine customized for the molecular profile of each individual's tumor. NEO-PV-01 in combination with nivolumab induced broad de novo neoantigen-specific immune response in 10 metastatic melanoma patients [123].

A phase 1 clinical trial to evaluate the safety and response of NEO-PV-01 in combination with pembrolizumab plus chemotherapy in patients with advanced or metastatic non-squamous non-small cell lung cancer is ongoing; results are not yet available [124].

EVAX-01-CAF09b is a personalized neoantigen vaccine with up to 15 peptides derived from somatic mutation of patient's cancer. A phase I study to evaluate the vaccine in combination with anti-PD-1/anti-PD-L1 inhibitor in patients with advanced NSCLC, melanoma, and kidney cancer is ongoing, no results available (NCT03715985).

ADXS-NEO is a live, attenuated Listeria monocytogenes (Lm) immunotherapy, using $\geq 20$ personal neoantigens and a truncated fragment of listeriolysin O (tLLO). Two patients experienced DLTs at 1X109 CFU dose level. Dose at 1X108 CFU was found to be safe and tolerated by one patient. ADXS-NEO is able to induce specific CD8+ T cells that recognized $90 \%$ of the 40 cancer neoantigen targets inserted in the $\mathrm{Lm}$ bacteria. The study is recruiting patients with advanced solid tumors for ADXS-NEO monotherapy or in combination with pembrolizumab [125].

\section{HDAC inhibitor and immunotherapy combination}

Histone deacetylase (HDAC) inhibitor may upregulate major histocompatibility protein (MHC) and PD-L1 thus enhancing the efficacy of immunotherapy.

ACY-241 is a HDAC6 inhibitor. In a phase Ib study, ACY-241 in combination with nivolumab was tested in platinum-treated and immunotherapy naïve advanced NSCLC patients. Eighteen patients were treated. Recommended phase 2 dose is $360 \mathrm{mg}$. Efficacy was evaluated in 13 patients, 8 had clinical benefit: 1 CR, 3 PR, 1 unconfirmed PR, and 3 SD. Commonly reported TEAEs included fatigue, arthralgia, and cough [126].

Entinostat is a HDAC1 and HDAC3 inhibitor. Entinostat plus pembrolizumab was evaluated in advanced NSCLC patients who had progressed on anti-PD-1/PDL1 therapy. Fifty-seven patients were enrolled, and 5 patients achieved a confirmed PR. The ORR was $9 \%$. The median duration of response is 4.2 months. The most common immune-related AEs were fatigue, anemia, decreased appetite, and diarrhea. Grade 3/4-related AEs occurred in $35.1 \%$ of patients [127].

Vorinostat is a HDAC inhibitor acts on class I, II, and IV of histone deacetylase. Vorinostat is FDA-approved for the treatment of cutaneous $\mathrm{T}$ cell lymphoma. In a phase I/Ib trial, vorinostat plus pembrolizumab was evaluated in patients with metastatic NSCLC that had been treated with or without immune checkpoint inhibitors (ICIs). Fourteen patients were enrolled to phase I and 20 patients were enrolled to phase Ib. The recommended phase 2 dose was $200 \mathrm{mg}$ of pembrolizumab and $300 \mathrm{mg}$ of vorinostat. Efficacy was evaluable in 30 patients, 6 were ICIs naïve and 24 ICIs-pretreated. The ORR was $13 \%(4 / 20)$ and SD was 53\% (16/30). In ICI-pretreated phase Ib cohort, 2 patients achieved PR and 10 had SD. The most commonly reported grade 3 AEs were myalgia, anemia, and diarrhea [128].

\section{BET inhibitor}

PLX51107 is a small molecule that exhibits interactions mediated by the four BET family proteins. PLX51107 is a novel drug targeting epigenetic approach. Phase Ib/IIa study results indicate that the MTD of PLX51107 is between 200 and $300 \mathrm{mg}$. Three patients had grade 3 TEAEs. One patient with NSCLC achieved SD [129]. 
Table 6 Summary of phase I/II clinical trials for advanced/metastatic NSCLC

\begin{tabular}{|c|c|c|c|c|c|c|c|}
\hline Drug Class & Drug & Mechanism of action & Study design & Clinical trial & Phase & Type of cancer & Status \\
\hline \multirow{22}{*}{$\begin{array}{l}\text { Targeted } \\
\text { therapy }\end{array}$} & Ensartinib & ALK inhibitor & Monotherapy & NCT03215693 & I & $\mathrm{NSCLC}$ & Recruiting \\
\hline & Ensartinib & ALK inhibitor & Monotherapy & NCT01625234 & $|/| \mid$ & NSCLC & Recruiting \\
\hline & $\begin{array}{l}\text { Repotrectinib } \\
\text { (TPX-0005) }\end{array}$ & ALK/ROS1/NTRK inhibitor & Monotherapy & NCT03093116 & I & $\begin{array}{l}\text { ALK/ROS1/ } \\
\text { NTRK+ solid } \\
\text { tumors }\end{array}$ & Recruiting \\
\hline & $\begin{array}{l}\text { M6620 (VX- } \\
970)\end{array}$ & ATR inhibitor & $\begin{array}{l}\text { Combination with } \\
\text { gemcitabine }\end{array}$ & NCT02157792 & I & NSCLC & $\begin{array}{l}\text { Active, not } \\
\text { recruiting }\end{array}$ \\
\hline & Bemcentinib & AXL inhibitor & $\begin{array}{l}\text { Combination with } \\
\text { docetaxel }\end{array}$ & NCT02922777 & $|/| \mid$ & $\mathrm{NSCLC}$ & Recruiting \\
\hline & Bemcentinib & AXL inhibitor & $\begin{array}{l}\text { Combination with } \\
\text { pembrolizumab }\end{array}$ & NCT03184571 & $\|$ & $\mathrm{NSCLC}$ & Recruiting \\
\hline & TP-0903 & AXL inhibitor & Monotherapy & NCT02729298 & 1 & $\begin{array}{l}\text { Advanced solid } \\
\text { tumors }\end{array}$ & Recruiting \\
\hline & Nazartinib & EGFR & Monotherapy & NCT02108964 & $\|$ & $\begin{array}{l}\text { EGFRmut solid } \\
\text { tumors }\end{array}$ & $\begin{array}{l}\text { Active, not } \\
\text { recruiting }\end{array}$ \\
\hline & BPI-7711 & EGFR 790 M inhibitor & Monotherapy & NCT03386955 & । & $\mathrm{NSCLC}$ & Recruiting \\
\hline & TAK-788 & $\begin{array}{l}\text { EGFR and HER2 TKI including } \\
\text { exon } 20 \text { insertions }\end{array}$ & Monotherapy & NCT02716116 & $|/| \mid$ & NSCLC & Recruiting \\
\hline & YH25448 & EGFR and T790M & Monotherapy & NCT03046992 & $|/| \mid$ & NSCLC & Recruiting \\
\hline & HS-10296 & EGFR inhibitor & Monotherapy & NCT02981108 & $|/| \mid$ & NSCLC & Recruiting \\
\hline & SPH1188-11 & EGFR inhibitor & Monotherapy & NCT03231475 & I & $\mathrm{NSCLC}$ & Recruiting \\
\hline & Poziotinib & $\begin{array}{l}\text { EGFR or HER2 exon } 20 \\
\text { inhibitor }\end{array}$ & Monotherapy & NCT03318939 & $\|$ & NSCLC & Recruiting \\
\hline & Pyrotinib & HER1/HER2/HER4 inhibitor & Monotherapy & NCT02834936 & I & NSCLC & Unknown \\
\hline & AMG510 & KRAS G21C inhibitor & Monotherapy & NCT03600883 & $|/| \mid$ & $\begin{array}{l}\text { KRAS g12C } \\
\text { mutation solid } \\
\text { tumors }\end{array}$ & Recruiting \\
\hline & MRTX849 & KRAS G21C inhibitor & Monotherapy & NCT03785249 & $|/| \mid$ & $\begin{array}{l}\text { KRAS g12C } \\
\text { mutation solid } \\
\text { tumors }\end{array}$ & Recruiting \\
\hline & $\begin{array}{l}\text { Capmatinib } \\
\text { (INC280) }\end{array}$ & MET inhibitor & $\begin{array}{l}\text { Monotherapy and in } \\
\text { combination with gefitinib }\end{array}$ & NCT02468661 & I & $\mathrm{NSCLC}$ & Recruiting \\
\hline & Tepotinib & MET inhibitor & Monotherapy & NCT02864992 & $\|$ & NSCLC & Recruiting \\
\hline & LOXO-292 & RET inhibitor & Monotherapy & NCT03157128 & । & RET $(+)$ cancers & Recruiting \\
\hline & DS-6051b & ROS1/NTRK inhibitor & Monotherapy & NCT02279433 & 1 & $\begin{array}{l}\text { ROS1 and NTRK } \\
\text { Advanced } \\
\text { carcinoma }\end{array}$ & $\begin{array}{l}\text { Active, not } \\
\text { recruiting }\end{array}$ \\
\hline & MP0250 & $\begin{array}{l}\text { VEGF and HGF neutralizing } \\
\text { DARPIN molecule }\end{array}$ & Monotherapy & NCT02194426 & । & $\begin{array}{l}\text { Advanced solid } \\
\text { tumors }\end{array}$ & Completed \\
\hline \multirow[t]{6}{*}{$\begin{array}{l}\text { Antibody-drug } \\
\text { conjugate }\end{array}$} & PF-7020 & $\begin{array}{l}\text { ADC targeting protein } \\
\text { tyrosine kinase } 7 \text { (PTK7) }\end{array}$ & Monotherapy & NCT02222922 & 1 & $\begin{array}{l}\text { Advanced solid } \\
\text { tumors }\end{array}$ & $\begin{array}{l}\text { Active, not } \\
\text { recruiting }\end{array}$ \\
\hline & BA3011 & Anti-AXL antibody & Monotherapy & NCT03425279 & $|/| \mid$ & $\begin{array}{l}\text { Advanced solid } \\
\text { tumors }\end{array}$ & Recruiting \\
\hline & EnaV & Anti-AXL antibody & Monotherapy & NCT02988817 & $|/| \mid$ & $\begin{array}{l}\text { Advanced solid } \\
\text { tumor }\end{array}$ & Recruiting \\
\hline & U3-1403 & $\begin{array}{l}\text { Anti-HER2 antibody-drug } \\
\text { conjugate }\end{array}$ & Monotherapy & NCT03260491 & I & $\mathrm{NSCLC}$ & Recruiting \\
\hline & Anetumab & $\begin{array}{l}\text { Anti-mesothelin IgG1 } \\
\text { antibody conjugated to the } \\
\text { maytansinoid tubulin } \\
\text { inhibitor DM4 }\end{array}$ & $\begin{array}{l}\text { Monotherapy or in } \\
\text { combination }\end{array}$ & NCT03102320 & I & $\begin{array}{l}\text { Advanced solid } \\
\text { tumors }\end{array}$ & Recruiting \\
\hline & BT1718 & $\begin{array}{l}\text { Bicycle drug conjugate, binds } \\
\text { MT1-MMP and linked to DM1 }\end{array}$ & Monotherapy & NCT03486730 & $|/| \mid$ & $\begin{array}{l}\text { Advanced solid } \\
\text { tumors }\end{array}$ & Recruiting \\
\hline
\end{tabular}


Table 6 Summary of phase I/II clinical trials for advanced/metastatic NSCLC (Continued)

\begin{tabular}{|c|c|c|c|c|c|c|c|}
\hline Drug Class & Drug & Mechanism of action & Study design & Clinical trial & Phase & Type of cancer & Status \\
\hline & JNJ-372 & $\begin{array}{l}\text { EGFR-cMet bispecific } \\
\text { antibody }\end{array}$ & Monotherapy & NCT02609776 & I & NSCLC & Recruiting \\
\hline & XMT-1522 & $\begin{array}{l}\text { HER-2 Targeting antibody- } \\
\text { drug conjugate }\end{array}$ & Monotherapy & NCT02952729 & । & $\begin{array}{l}\text { Her } 2 \text { expressing } \\
\text { breast, lung, and } \\
\text { gastric cancer }\end{array}$ & $\begin{array}{l}\text { Active, not } \\
\text { recruiting }\end{array}$ \\
\hline & DS-1062a & $\begin{array}{l}\text { TROP2-targeting antibody- } \\
\text { drug conjugate }\end{array}$ & Monotherapy & NCT03401385 & । & $\begin{array}{l}\text { Advanced solid } \\
\text { tumors }\end{array}$ & Recruiting \\
\hline & DS-8201a & $\begin{array}{l}\text { HER-2 Targeting antibody- } \\
\text { drug conjugate }\end{array}$ & Monotherapy & NCT02564900 & । & $\begin{array}{l}\text { HER2 expression } \\
\text { solid tumors }\end{array}$ & $\begin{array}{l}\text { Active, not } \\
\text { recruiting }\end{array}$ \\
\hline \multirow[t]{2}{*}{ Cell therapy } & $\begin{array}{l}\text { MAGE-A10 T } \\
\text { cell therapy }\end{array}$ & $\begin{array}{l}\text { Affinity-enhanced T cells } \\
\text { against MAGE A10 antigen }\end{array}$ & Monotherapy & $\begin{array}{l}\text { NCT02592577/ } \\
\text { NCT02989064 }\end{array}$ & 1 & $\begin{array}{l}\text { Advanced solid } \\
\text { tumors }\end{array}$ & Recruiting \\
\hline & $\begin{array}{l}\text { CRISP/Cas9- } \\
\text { mediated } \\
\text { knockout of } \\
\text { PD-1 gene }\end{array}$ & $\begin{array}{l}\text { T lymphocytes with PD-1 } \\
\text { gene knockout }\end{array}$ & Monotherapy & NCT02793856 & I & NSCLC & $\begin{array}{l}\text { Active, not } \\
\text { recruiting }\end{array}$ \\
\hline $\begin{array}{l}\text { Cytokine } \\
\text { therapy }\end{array}$ & ALT-803 & IL-15 superagonist & $\begin{array}{l}\text { Combination with } \\
\text { nivolumab }\end{array}$ & NCT02523469 & $|/| \mid$ & NSCLC & $\begin{array}{l}\text { Active, not } \\
\text { recruiting }\end{array}$ \\
\hline $\begin{array}{l}\text { Immuno- } \\
\text { Conjugate }\end{array}$ & L-DOS47 & Urease immuno-conjugate & $\begin{array}{l}\text { Combination with } \\
\text { cisplatin+vinorolbine }\end{array}$ & NCT03891173 & $|/| \mid$ & NSCLC & Recruiting \\
\hline $\begin{array}{l}\text { Immuno- } \\
\text { Conjugate }\end{array}$ & L-DOS47 & Urease immuno-conjugate & $\begin{array}{l}\text { Combination with } \\
\text { carbo+pemetrexed }\end{array}$ & NCT02309892 & $|/| \mid$ & NSCLC & Recruiting \\
\hline \multirow[t]{17}{*}{ Immunotherapy } & NIR178 & A2AR antagonist & Monotherapy & NCT02403193 & $|/| \mid$ & NSCLC & Recruiting \\
\hline & PBF-1129 & Anti-A2aR & Monotherapy & NCT03274479 & । & NSCLC & Recruiting \\
\hline & $\begin{array}{l}\text { AB928 and } \\
\text { AB122 }\end{array}$ & $\begin{array}{l}\text { Anti-A2aR and A2bR, Anti- } \\
\text { PD-1 }\end{array}$ & $\begin{array}{l}\text { Monotherapy and } \\
\text { combination therapies }\end{array}$ & NCT03846310 & । & NSCLC & Recruiting \\
\hline & REGN4659 & Anti-CTLA-4 & $\begin{array}{l}\text { Combination with } \\
\text { cemiplimab }\end{array}$ & NCT03580694 & । & NSCLC & Recruiting \\
\hline & $\begin{array}{l}\text { BMS-986253 } \\
\text { (HuMax-IL8) }\end{array}$ & $\begin{array}{l}\text { Anti-IL-8 monoclonal } \\
\text { antibody }\end{array}$ & Monotherapy & NCT02536469 & । & $\begin{array}{l}\text { Advanced solid } \\
\text { tumors }\end{array}$ & Completed \\
\hline & MSC-1 & $\begin{array}{l}\text { Anti-leukemia inhibitory } \\
\text { factor(LIF) antibody }\end{array}$ & Monotherapy & NCT03490669 & । & $\begin{array}{l}\text { Advanced solid } \\
\text { tumors }\end{array}$ & $\begin{array}{l}\text { Active, not } \\
\text { recruiting }\end{array}$ \\
\hline & Cemiplimab & Anti-PD-1 & Monotherapy & NCT02383212 & । & $\begin{array}{l}\text { Advanced } \\
\text { malignancies }\end{array}$ & $\begin{array}{l}\text { Active, not } \\
\text { recruiting }\end{array}$ \\
\hline & JSO01 & Anti-PD-1 & Monotherapy & NCT02836834 & । & $\begin{array}{l}\text { Advanced or } \\
\text { recurrent } \\
\text { malignancies }\end{array}$ & $\begin{array}{l}\text { Active, not } \\
\text { recruiting }\end{array}$ \\
\hline & PDR001 & Anti-PD-1 & $\begin{array}{l}\text { Combination with } \\
\text { platinum doublet }\end{array}$ & NCT03064854 & । & NSCLC & Recruiting \\
\hline & SHR-1210 & Anti-PD-1 & Combination with apatinib & NCT03083041 & $|/| \mid$ & NSCLC & Unknown \\
\hline & Tislelizumab & Anti-PD-1 & $\begin{array}{l}\text { Combination with } \\
\text { chemotherapy }\end{array}$ & NCT03432598 & $\|$ & NSCLC & Recruiting \\
\hline & NC318 & Siglec-15 antibody & Monotherapy & NCT03665285 & । & $\begin{array}{l}\text { Advanced solid } \\
\text { tumors }\end{array}$ & Recruiting \\
\hline & $\begin{array}{l}\text { TSR-022,TSR } \\
\text { 042, TSR033 }\end{array}$ & $\begin{array}{l}\text { Anti-TIM-3, Anti-PD-1, and } \\
\text { anti-LGA3 }\end{array}$ & $\begin{array}{l}\text { Monotherapy and in } \\
\text { Combination }\end{array}$ & NCT02817633 & । & $\begin{array}{l}\text { Advanced } \\
\text { tumor }\end{array}$ & Recruiting \\
\hline & $\begin{array}{l}\text { Eftilagimod } \\
\text { alpha }\end{array}$ & LAG-3 fusion protein & $\begin{array}{l}\text { Combination with } \\
\text { pembrolizumab }\end{array}$ & NCT03625323 & $\|$ & $\begin{array}{l}\text { NSCLC and } \\
\text { HNSCC }\end{array}$ & Recruiting \\
\hline & NKTR-214 & CD122-biased agonist & $\begin{array}{l}\text { Combination with } \\
\text { nivolumab }\end{array}$ & NCT02983045 & $|/| \mid$ & $\begin{array}{l}\text { Advanced } \\
\text { cancers }\end{array}$ & Recruiting \\
\hline & NKTR-214 & CD122-Biased Cytokine & $\begin{array}{l}\text { Combination with } \\
\text { pembrolizumab or } \\
\text { atezolizumab }\end{array}$ & NCT03138889 & । & NSCLC & Recruiting \\
\hline & APX005M & CD40 agonistic antibody & $\begin{array}{l}\text { Combination with } \\
\text { nivolumab }\end{array}$ & NCT03123783 & $|/| \mid$ & NSCLC & Recruiting \\
\hline
\end{tabular}


Table 6 Summary of phase I/II clinical trials for advanced/metastatic NSCLC (Continued)

\begin{tabular}{|c|c|c|c|c|c|c|c|}
\hline Drug Class & Drug & Mechanism of action & Study design & Clinical trial & Phase & Type of cancer & Status \\
\hline & SEA-CD40 & CD40 Antibody & $\begin{array}{l}\text { Monotherapy and in } \\
\text { Combination with } \\
\text { pembrolizumab }\end{array}$ & NCT02376699 & I & $\begin{array}{l}\text { Relapsed/ } \\
\text { refractory } \\
\text { metastatic solid } \\
\text { tumors }\end{array}$ & Recruiting \\
\hline & ALX148 & CD47 blocker & $\begin{array}{l}\text { Monotherapy and } \\
\text { combination with } \\
\text { pembrolizumab, } \\
\text { trastuzumab, or rituximab }\end{array}$ & NCT03013218 & 1 & $\begin{array}{l}\text { Advanced solid } \\
\text { tumors and } \\
\text { lymphoma }\end{array}$ & Recruiting \\
\hline & 10102 & IDO vaccine & $\begin{array}{l}\text { Combination with } \\
\text { pembrolizumab with or } \\
\text { without chemotherapy }\end{array}$ & NCT03562871 & |//I & NSCLC & Recruiting \\
\hline & Epacadostat & IDO1 inhibitor & $\begin{array}{l}\text { Combination with } \\
\text { pembrolizumab }\end{array}$ & NCT02178722 & |/II & Solid tumors & $\begin{array}{l}\text { Active, not } \\
\text { recruiting }\end{array}$ \\
\hline & Bl1361849 & mRNA vaccine & $\begin{array}{l}\text { Combination with } \\
\text { durvalumab and/or } \\
\text { tremelimumab }\end{array}$ & NCT03164772 & |//I & NSCLC & Recruiting \\
\hline & $\begin{array}{l}\text { EVAX-01- } \\
\text { CAF09b }\end{array}$ & Neo-antigen vaccine & Montherapy & NCT03715985 & । & $\begin{array}{l}\text { Advanced solid } \\
\text { tumors }\end{array}$ & Recruiting \\
\hline & NEO-PV-01 & Personal neoantigen vaccine & $\begin{array}{l}\text { Combination with } \\
\text { pembrolizumab } \\
\text { +chemotherapy }\end{array}$ & NCT03380871 & । & NSCLC & $\begin{array}{l}\text { Active, not } \\
\text { Recruiting }\end{array}$ \\
\hline & ADXS-NEO & $\begin{array}{l}\text { Personalized neoantigen- } \\
\text { listeria vaccine }\end{array}$ & $\begin{array}{l}\text { Monotherapy and } \\
\text { combination with } \\
\text { pembrolizumab }\end{array}$ & NCT03265080 & । & $\begin{array}{l}\text { Advanced } \\
\text { tumor }\end{array}$ & Recruiting \\
\hline & LYC-55716 & RORy agonist & $\begin{array}{l}\text { Combination with } \\
\text { pembrolizumab }\end{array}$ & NCT03396497 & । & NSCLC & $\begin{array}{l}\text { Active, not } \\
\text { recruiting }\end{array}$ \\
\hline & LN-144/LN-145 & $\begin{array}{l}\text { Tumor-infiltrating } \\
\text { lymphocytes }\end{array}$ & $\begin{array}{l}\text { Monotherapy and } \\
\text { combination with } \\
\text { pembrolizumab }\end{array}$ & NCT03645928 & $\|$ & NSCLC & Recruiting \\
\hline & CV301 & Vaccine & $\begin{array}{l}\text { Combination with } \\
\text { pembrolizumab }\end{array}$ & NCT02840994 & 1 & NSCLC & $\begin{array}{l}\text { Active, not } \\
\text { recruiting }\end{array}$ \\
\hline & DCVAC & Vaccine & $\begin{array}{l}\text { Combination with } \\
\text { chemotherapy }\end{array}$ & NCT02470468 & |//I & NSCLC & $\begin{array}{l}\text { Active, not } \\
\text { recruiting }\end{array}$ \\
\hline & UCPVax & Vaccine & Montherapy & NCT02818426 & |/II & NSCLC & Recruiting \\
\hline & Debio 1143 & Smac mimetics & $\begin{array}{l}\text { Combination with } \\
\text { avelumab }\end{array}$ & NCT03270176 & 1 & NSCLC & Recruiting \\
\hline \multirow[t]{4}{*}{$\begin{array}{l}\text { Tumor } \\
\text { epigenetics }\end{array}$} & ACY 241 & HDAC inhibitors & $\begin{array}{l}\text { Combination with } \\
\text { nivolumab }\end{array}$ & NCT02635061 & 1 & NSCLC & Recruiting \\
\hline & PLX51107 & BET inhibitor & Monotherapy & NCT02683395 & $\mathrm{lb} / \| \mathrm{la}$ & $\begin{array}{l}\text { advanced } \\
\text { hematological } \\
\text { and solid } \\
\text { tumors }\end{array}$ & Terminated \\
\hline & Entinostat & HDAC inhibitors & $\begin{array}{l}\text { Combination with } \\
\text { pembrolizumab }\end{array}$ & NCT02437136 & |/II & NSCLC & $\begin{array}{l}\text { Active, not } \\
\text { recruiting }\end{array}$ \\
\hline & Vorinostat & HDAC inhibitors & $\begin{array}{l}\text { Combination with } \\
\text { pembrolizumab }\end{array}$ & NCT02638090 & |/II & NSCLC & Recruiting \\
\hline
\end{tabular}

\section{SMAC mimetics}

Debio 1143 is an oral antagonist of IAPs (inhibitor of apoptosis proteins) increased PD-1/PD-L1 expression and tumor-infiltrating lymphocytes thus synergizes with PD1/ PDL1 inhibitors in preclinical models. Debio 1143 promotes apoptosis of cancer cells by mimicking the activity of second mitochondria-derived activator of caspase (SMAC).
Sixteen advanced solid tumors patients were treated with Debio 1143 plus avelumab In a phase I study. One patient had DLT at Debio $1143250 \mathrm{mg}$ /day dose (grade 3 ALT/AST increase). Most TEAEs were grade 1 or 2 . Efficacy was evaluable in 15 patients, one had PR (NSCLC) and five had SD. Two other NSCLC patients had $>15 \%$ tumor shrinkage [130]. 


\section{Conclusions}

Significant advances have been made in the treatment of advanced and metastatic NSCLC. We have seen median survival improved from 4 to 6 months with best supportive care then progress to 8-17 months with chemotherapy. Currently, with targeted therapy and immunotherapy, the median overall survival rate for this devastating disease is estimated to be $18-36$ months and some have long-term survival. The 5-year overall survival was about 4-6\% percent and now the 5-year survival rate when treated with immunotherapy is $15-20 \%$. The median OS is more than 3 years for EGFR mutant patients with EGFR TKIs and patients with ALK rearrangements also enjoy long-term survival with multiple lines of ALK TKIs. However, targetable mutations are not present in all patients. Patients that are on targeted therapy or immunotherapy will eventually develop treatment resistance. Identifying new targets, understanding the resistance mechanisms and developing novel agents or strategies to overcome the resistance are needed. Although immunotherapy can provide durable response and long-term survival in some patients, a significant percentage of patients may not benefit from it and some may develop super progression after initiation of immunotherapy. Efforts to find reliable biomarkers to guide the selection of patients who may benefit from immunotherapy are undergoing.

In the past decade, the FDA has approved multiple targeted agents for patients who have actionable mutations such as EGFR, ALK, ROS1, BRAF, and NTRK. Promising targeted agents for KRAS G12C, RET, MET, and AXL as well as other mutations are being currently investigated and could receive approval in the near future. For patients who do not have actionable mutations, the best alternatives are immunotherapy alone if PD-L1 expression is more than $50 \%$ or in combination with chemotherapy if PD-L1 with low expression. The exploration of immunotherapy in advanced/metastatic NSCLC has been beyond anti-PD-1/PD-L1 and CTLA pathway. Immunotherapy to stimulate immune response through other pathways such as IDO, TIM, LAG-3, CD40, and CD122 are encouraging. Innovative treatments such as neoantigen vaccine and antibody-drug conjugate are also being tested in this patient population (Table 6).

The study and treatment innovations in advanced and metastatic NSCLC are probably one of the most active and promising in the field of metastatic solid tumors.

\section{Abbreviations}

DCR: Disease control rate; FDA: Food and Drug Administration; NSCLC: Nonsmall cell lung cancer; ORR: Overall response rare; OS: Overall survival; PD: Progressive disease; PR: Partial response; SD: Stable disease; TEAEs: Treatment-emergent adverse events; TPS: Tumor proportion score
}

\section{Acknowledgements}

The authors would like to acknowledge the National Cancer Institute K12CA090628 grant for the support to Dr. Lou.

\section{Authors' contributions}

Conception and design-Drs. Lou and Chen. Collection and assembly of data-Drs. Chen, Shi, Zhang, Zhao, and Zhou. Data analysis and interpretation-Drs. Chen, Azzouqa, Manochakian, Zhao, Shi, Zhou, and Lou and Ms. James. Manuscript writing-Drs. Chen, Lou, Manochakian, Azzouqa, and Zhang and Ms. James. All authors reviewed and edited the manuscript. Final approval of the article-all authors.

\section{Funding}

This work was supported by the Paul Calabresi Career Development Award for Clinical Oncology (K12)—National Cancer Institute.

Awardee: Yanyan Lou

Availability of data and materials

All data and materials used for this study are included in this article.

Ethics approval and consent to participate

Not applicable

Consent for publication

Not applicable

\section{Competing interests}

The authors declare that they have no competing interests.

Received: 15 February 2020 Accepted: 23 April 2020

Published online: 24 May 2020

\section{References}

1. Siegel RL, Miller KD, Jemal A: Cancer statistics, 2020. CA: A Cancer Journal for Clinicians 2020, 70(1):7-30.

2. Chemotherapy in non-small cell lung cancer: a meta-analysis using updated data on individual patients from 52 randomised clinical trials. Non-small Cell Lung Cancer Collaborative Group. BMJ. 1995;311(7010):899-909.

3. Spiro SG, Silvestri GA. One hundred years of lung cancer. Am J Respir Crit Care Med. 2005;172(5):523-9.

4. Ciuleanu T, Brodowicz T, Zielinski C, Kim JH, Krzakowski M, Laack E, Wu YL, Bover I, Begbie S, Tzekova V, et al. Maintenance pemetrexed plus best supportive care versus placebo plus best supportive care for non-small-cell lung cancer: a randomised, double-blind, phase 3 study. Lancet. 2009; 374(9699):1432-40.

5. Paz-Ares $L$, de Marinis F, Dediu M, Thomas M, Pujol JL, Bidoli P, Molinier O, Sahoo TP, Laack E, Reck M, et al. Maintenance therapy with pemetrexed plus best supportive care versus placebo plus best supportive care after induction therapy with pemetrexed plus cisplatin for advanced nonsquamous non-small-cell lung cancer (PARAMOUNT): a double-blind, phase 3, randomised controlled trial. Lancet Oncol. 2012;13(3):247-55.

6. Paz-Ares LG, Fd M, Dediu M, Thomas M, Pujol J-L, Bidoli P, Molinier O, Sahoo TP, Laack E, Reck M, et al. PARAMOUNT: final overall survival results of the phase III study of maintenance pemetrexed versus placebo immediately after induction treatment with pemetrexed plus cisplatin for advanced nonsquamous non-small-cell lung cancer. Journal of Clinical Oncology. 2013;31(23):2895-902.

7. Lin JJ, Cardarella S, Lydon CA, Dahlberg SE, Jackman DM, Janne PA, Johnson BE. Five-year survival in EGFR-mutant metastatic lung adenocarcinoma treated with EGFR-TKIs. Journal of thoracic oncology : official publication of the International Association for the Study of Lung Cancer. 2016;11(4):556-65.

8. Mok TS, Wu YL, Thongprasert S, Yang CH, Chu DT, Saijo N, Sunpaweravong P, Han B, Margono B, Ichinose Y, et al. Gefitinib or carboplatin-paclitaxel in pulmonary adenocarcinoma. N Engl J Med. 2009;361(10):947-57.

9. Ramalingam SS, Vansteenkiste J, Planchard D, Cho BC, Gray JE, Ohe Y, Zhou C, Reungwetwattana T, Cheng Y, Chewaskulyong B, et al. Overall survival with osimertinib in untreated, EGFR-mutated advanced NSCLC. N Engl J Med. 2020;382(1):41-50.

10. Gettinger $S$, Horn L, Jackman D, Spigel D, Antonia S, Hellmann M, Powderly J, Heist R, Sequist LV, Smith DC, et al. Five-year follow-up of nivolumab in previously treated advanced non-small-cell lung cancer: results from the CA209-003 study. Journal of Clinical Oncology, 1684. 2018;36(17):1675.

11. Garon EB, Hellmann MD, Rizvi NA, Carcereny E, Leighl NB, Ahn M-J, Eder JP, Balmanoukian AS, Aggarwal C, Horn L et al: Five-year overall survival for 
patients with advanced non-small-cell lung cancer treated with pembrolizumab: results from the phase I KEYNOTE-001 study. Journal of Clinical Oncology, O(0):JCO.19.00934.

12. Kim D-W, Tan DS-W, Aix SP, Sequist LV, Smit EF, Hida T, Yang JC-H, Felip E, Seto T, Grohé $C$ et al: Preliminary phase II results of a multicenter, openlabel study of nazartinib (EGF816) in adult patients with treatment-naïve EGFR-mutant non-small cell lung cancer (NSCLC). Journal of Clinical Oncology 2018, 36(15_suppl):9094-9094.

13. Shi Y, Fang J, Shu Y, Wang D, Yu H, Zhao Y, Zhang L, Zhu B, Li X, Chen G et al: A phase I study to evaluate safety, tolerability, pharmacokinetics and antineoplastic activity of BPI-7711 in patients with EGFR/T790M mutation advanced or recurrent NSCLC. Journal of Clinical Oncology 2019, 37(15_suppl):9034-9034.

14. Ahn M-J, Han J-Y, Kim S-W, Lee KH, Kim D-W, Lee Y-G, Cho EK, Lee G-W, Lee J-S, Kim J-H et al: Lazertinib, a 3rd generation EGFR-TKI, in patients with EGFR-TKI resistant NSCLC: updated results of phase I/II Study. Journal of Clinical Oncology 2019, 37(15_suppl):9037-9037.

15. Lu S, Camidge R, Yang C, Zhou J, Guo R, Chiu C, Chang G, Shiah H, Chen Y, Wang C et al: P1.01-62 The third generation irreversible EGFR inhibitor HS10296 in advanced non-small cell lung cancer patients. Journal of Thoracic Oncology 2018, 13(10):S485.

16. Doebele RC, Riely GJ, Spira Al, Horn L, Piotrowska Z, Costa DB, Neal JW, Zhang S, Reichmann W, Kerstein D et al: First report of safety, PK, and preliminary antitumor activity of the oral EGFR/HER2 exon 20 inhibitor TAK788 (AP32788) in non-small cell lung cancer (NSCLC). Journal of Clinical Oncology 2018, 36(15_suppl):9015-9015.

17. Janne PA, Neal JW, Camidge DR, Spira Al, Piotrowska Z, Horn L, Costa DB, Tsao AS, Patel JD, Gadgeel SM et al: Antitumor activity of TAK-788 in NSCLC with EGFR exon 20 insertions. Journal of Clinical Oncology 2019, 37(15_ suppl):9007-9007.

18. Piotrowska Z, Thress KS, Mooradian M, Heist RS, Azzoli CG, Temel JS, Rizzo C, Nagy RJ, Lanman RB, Gettinger SN et al: MET amplification (amp) as a resistance mechanism to osimertinib. Journal of Clinical Oncology 2017, 35(15_suppl):9020-9020.

19. Ma C, Wei S, Song Y: T790M and acquired resistance of EGFR TKl: a literature review of clinical reports. J Thorac Dis 2011, 3(1):10-18.

20. Leonetti A, Sharma S, Minari R, Perego P, Giovannetti E, Tiseo M: Resistance mechanisms to osimertinib in EGFR-mutated non-small cell lung cancer. British journal of cancer 2019, 121(9):725-737.

21. Sequist LV, Han JY, Ahn MJ, Cho BC, Yu H, Kim SW, Yang JC, Lee JS, Su WC, Kowalski D et al: Osimertinib plus savolitinib in patients with EGFR mutation-positive, MET-amplified, non-small-cell lung cancer after progression on EGFR tyrosine kinase inhibitors: interim results from a multicentre, open-label, phase 1b study. Lancet Oncol 2020, 21(3):373-386.

22. Kwak EL, Bang YJ, Camidge DR, Shaw AT, Solomon B, Maki RG, Ou SH, Dezube BJ, Janne PA, Costa DB et al: Anaplastic lymphoma kinase inhibition in non-small-cell lung cancer. N Engl J Med 2010, 363(18):1693-1703.

23. Gainor JF, Varghese AM, Ou SH, Kabraji S, Awad MM, Katayama R, Pawlak A, Mino-Kenudson M, Yeap BY, Riely GJ et al: ALK rearrangements are mutually exclusive with mutations in EGFR or KRAS: an analysis of 1,683 patients with non-small cell lung cancer. Clin Cancer Res 2013, 19(15):4273-4281.

24. Solomon BJ, Mok T, Kim DW, Wu YL, Nakagawa K, Mekhail T, Felip E, Cappuzzo F, Paolini J, Usari T et al: First-line crizotinib versus chemotherapy in ALK-positive lung cancer. N Engl J Med 2014, 371(23):2167-2177.

25. Peters S, Camidge DR, Shaw AT, Gadgeel S, Ahn JS, Kim DW, Ou SI, Perol M, Dziadziuszko R, Rosell $R$ et al: Alectinib versus crizotinib in untreated ALKpositive non-small-cell lung cancer. N Engl J Med 2017, 377(9):829-838.

26. Camidge DR, Peters S, Mok T, Gadgeel SM, Cheema PK, Pavlakis N, Marinis FD, Stroyakovskiy DL, Cho BC, Zhang L et al: Updated efficacy and safety data from the global phase III ALEX study of alectinib (ALC) vs crizotinib (CZ) in untreated advanced ALK+ NSCLC. Journal of Clinical Oncology 2018, 36(15_suppl):9043-9043.

27. Camidge DR, Kim HR, Ahn MJ, Yang JC, Han JY, Lee JS, Hochmair MJ, Li JY, Chang GC, Lee KH et al: Brigatinib versus crizotinib in ALK-positive nonsmall-cell lung cancer. N Engl J Med 2018, 379(21):2027-2039.

28. Shaw AT, Kim TM, Crino L, Gridelli C, Kiura K, Liu G, Novello S, Bearz A, Gautschi O, Mok T et al: Ceritinib versus chemotherapy in patients with ALK-rearranged non-small-cell lung cancer previously given chemotherapy and crizotinib (ASCEND-5): a randomised, controlled, open-label, phase 3 trial. Lancet Oncol 2017, 18(7):874-886.

29. Solomon BJ, Besse B, Bauer TM, Felip E, Soo RA, Camidge DR, Chiari R, Bearz A, Lin CC, Gadgeel SM et al: Lorlatinib in patients with ALK-positive non- small-cell lung cancer: results from a global phase 2 study. Lancet Oncol 2018, 19(12):1654-1667.

30. Horn L, Infante JR, Reckamp KL, Blumenschein GR, Leal TA, Waqar SN, Gitlitz BJ, Sanborn RE, Whisenant JG, Du L et al: Ensartinib (X-396) in ALK-positive non-small cell lung cancer: results from a first-in-human phase $1 / I$, multicenter study. Clinical cancer research : an official journal of the American Association for Cancer Research 2018, 24(12):2771-2779.

31. Horn L, Wu Y-L, Reck M, Wakelee HA, Liang C, Tan F, Harrow K, Oertel V, Dukart G, Mok T: eXalt3: Phase 3 randomized study comparing ensartinib to crizotinib in anaplastic lymphoma kinase (ALK) positive non-small cell lung cancer (NSCLC) patients. Journal of Clinical Oncology 2018, 36(15_suppl): TPS9115-TPS9115.

32. Shaw AT, Riely GJ, Bang YJ, Kim DW, Camidge DR, Solomon BJ, VarellaGarcia M, lafrate AJ, Shapiro GI, Usari T et al: Crizotinib in ROS1-rearranged advanced non-small-cell lung cancer (NSCLC): updated results, including overall survival, from PROFILE 1001. Annals of oncology : official journal of the European Society for Medical Oncology 2019.

33. Lim SM, Kim HR, Lee JS, Lee KH, Lee YG, Min YJ, Cho EK, Lee SS, Kim BS, Choi MY et al: Open-label, multicenter, phase II study of ceritinib in patients with non-small-cell lung cancer harboring ROS1 rearrangement. J Clin Oncol 2017, 35(23):2613-2618.

34. Ou S, Shaw A, Riely G, Chiari R, Bauman J, Clancy J, Thurm H, Peltz G, Abbattista A, Solomon B: OA02.03 clinical activity of lorlatinib in patients with ROS1+ advanced non-small cell lung cancer: phase 2 study cohort EXP-6. Journal of Thoracic Oncology 2018, 13(10):S322-S323.

35. Drilon A, Laetsch TW, Kummar S, DuBois SG, Lassen UN, Demetri GD, Nathenson M, Doebele RC, Farago AF, Pappo AS et al: Efficacy of larotrectinib in TRK fusion-positive cancers in adults and children. N Engl J Med 2018, 378(8):731-739.

36. Demetri GD, Paz-Ares L, Farago AF, Liu SV, Chawla SP, Tosi D, Kim ES, Blakely CM, Krauss JC, Sigal D et al: LBA4Efficacy and safety of entrectinib in patients with NTRK fusion-positive tumours: pooled analysis of STARTRK-2, STARTRK-1, and ALKA-372-001. Annals of Oncology 2018, 29(suppl_9).

37. Siena S, Doebele RC, Shaw AT, Karapetis CS, Tan DS-W, Cho BC, Kim D-W, Ahn M-J, Krebs M, Goto K et al: Efficacy of entrectinib in patients (pts) with solid tumors and central nervous system (CNS) metastases: Integrated analysis from three clinical trials. Journal of Clinical Oncology 2019, 37(15_ suppl):3017-3017.

38. Papadopoulos KP, Gandhi L, Janne PA, Ou S-HI, Shaw A, Goldberg TR, Greenberg J, Gu X, Tachibana M, Senaldi G et al: First-in-human study of DS-6051b in patients (pts) with advanced solid tumors (AST) conducted in the US. Journal of Clinical Oncology 2018, 36(15_suppl):2514-2514.

39. Drilon AE, Ou S-HI, Cho BC, Kim D-W, Lee J, Lin JJ, Zhu WW, Kim H, Kim TM, Ahn M-J et al: A phase 1 study of the next-generation ALK/ROS1/TRK inhibitor ropotrectinib (TPX-0005) in patients with advanced ALK/ROS1/ NTRK+ cancers (TRIDENT-1). Journal of Clinical Oncology 2018, 36(15_suppl): 2513-2513.

40. Cho BC, Drilon AE, Doebele RC, Kim D-W, Lin JJ, Lee J, Ahn M-J, Zhu WW, Ejadi S, Camidge DR et al: Safety and preliminary clinical activity of repotrectinib in patients with advanced ROS1 fusion-positive non-small cell lung cancer (TRIDENT-1 study). Journal of Clinical Oncology 2019, 37(15_ suppl):9011-9011.

41. Planchard D, Smit EF, Groen HJM, Mazieres J, Besse B, Helland A, Giannone V, D'Amelio AM Jr, Zhang P, Mookerjee B, et al. Dabrafenib plus trametinib in patients with previously untreated BRAF(V600E)-mutant metastatic nonsmall-cell lung cancer: an open-label, phase 2 trial. Lancet Oncol. 2017; 18(10):1307-16.

42. Odogwu L, Mathieu L, Blumenthal G, Larkins E, Goldberg KB, Griffin N, Bijwaard K, Lee EY, Philip R, Jiang $X$, et al. FDA approval summary: dabrafenib and trametinib for the Treatment of metastatic non-small cell lung cancers harboring BRAF V600E mutations. Oncologist. 2018;23(6):740-5.

43. Awad MM, Oxnard GR, Jackman DM, Savukoski DO, Hall D, Shivdasani P, Heng JC, Dahlberg SE, Janne PA, Verma S, et al. MET exon 14 mutations in non-small-cell lung cancer are associated with advanced age and stagedependent MET genomic amplification and c-Met overexpression. J Clin Oncol. 2016:34(7):721-30.

44. Camidge DR, Otterson GA, Clark JW, Ou S-HI, Weiss J, Ades S, Conte U, Tang Y, Wang SC-E, Murphy D et al: Crizotinib in patients (pts) with METamplified non-small cell lung cancer (NSCLC): Updated safety and efficacy findings from a phase 1 trial. Journal of Clinical Oncology 2018, 36(15_ suppl):9062-9062. 
45. Paik PK, Drilon A, Fan PD, Yu H, Rekhtman N, Ginsberg MS, Borsu L, Schultz $\mathrm{N}$, Berger MF, Rudin CM, et al. Response to MET inhibitors in patients with stage IV lung adenocarcinomas harboring MET mutations causing exon 14 skipping. Cancer Discov. 2015;5(8):842-9.

46. Wolf J, Seto T, Han J-Y, Reguart N, Garon EB, Groen HJM, Tan DS-W, Hida T, Jonge MJD, Orlov SV et al: Capmatinib (INC280) in METAex14-mutated advanced non-small cell lung cancer (NSCLC): Efficacy data from the phase II GEOMETRY mono-1 study. Journal of Clinical Oncology 2019, 37(15_ suppl):9004-9004.

47. Paik PK, Veillon R, Cortot AB, Felip E, Sakai H, Mazieres J, Griesinger F, Horn L, Senellart H, Meerbeeck JPV et al: Phase II study of tepotinib in NSCLC patients with METex14 mutations. Journal of Clinical Oncology 2019, 37(15_ suppl):9005-9005.

48. Drilon A, Rekhtman N, Arcila M, Wang L, Ni A, Albano M, Van Voorthuysen M, Somwar R, Smith RS, Montecalvo J, et al. Cabozantinib in patients with advanced RET-rearranged non-small-cell lung cancer: an open-label, singlecentre, phase 2, single-arm trial. Lancet Oncol. 2016;17(12):1653-60.

49. Yoh K, Seto T, Satouchi M, Nishio M, Yamamoto N, Murakami H, Nogami N, Matsumoto S, Kohno T, Tsuta K, et al. Vandetanib in patients with previously treated RET-rearranged advanced non-small-cell lung cancer (LURET): an open-label, multicentre phase 2 trial. The Lancet Respiratory medicine. 2017; 5(1):42-50.

50. Lee SH, Lee JK, Ahn MJ, Kim DW, Sun JM, Keam B, Kim TM, Heo DS, Ahn JS, Choi $Y$ L, et al. Vandetanib in pretreated patients with advanced non-small cell lung cancer-harboring RET rearrangement: a phase II clinical trial. Annals of oncology : official journal of the European Society for Medical Oncology. 2017;28(2):292-7.

51. V. Velcheti1 TH, K.L. Reckamp3, J.C. Yang4, H. Nokihara5, P. Sachdev6, K. Feit6, T. Kubota7, T. Nakada7: Phase 2 study of lenvatinib $(L N)$ in patients (Pts) with RET fusion-positive adenocarcinoma of the lung. Annals of oncology : official journal of the European Society for Medical Oncology 2016, 27(supplement 6):416-454.

52. Gautschi O, Milia J, Filleron T, Wolf J, Carbone DP, Owen D, Camidge R, Narayanan V, Doebele RC, Besse B, et al. Targeting RET in patients with RETrearranged lung cancers: results from the global, multicenter RET registry. Journal of Clinical Oncology. 2017;35(13):1403-10.

53. A.E. Drilon SL, R. Doebele, C. Rodriguez, M. Fakih, K.L. Reckamp, L.1. Bazhenova, B.C. Cho, E. Kowack, J. Oliver, P. Multani, M. Ahn: A Phase 1b study of RXDX105, a VEGFR-sparing potent RET inhibitor, in RETi-naïve patients with RET fusion-positive NSCLC. Annals of Oncology 2017, 28(5): v605-v649.

54. Subbiah V, Gainor JF, Rahal R, Brubaker JD, Kim JL, Maynard M, Hu W, Cao Q, Sheets MP, Wilson D, et al. Precision targeted therapy with BLU-667 for RET-driven cancers. Cancer Discovery. 2018;8(7):836-49.

55. Gainor JF, Lee DH, Curigliano G, Doebele RC, Kim D-W, Baik CS, Tan DS-W, Lopes G, Gadgeel SM, Cassier PA et al: Clinical activity and tolerability of BLU-667, a highly potent and selective RET inhibitor, in patients (pts) with advanced RET-fusion+ non-small cell lung cancer (NSCLC). Journal of Clinical Oncology 2019, 37(15_suppl):9008-9008.

56. Drilon AE, Subbiah V, Oxnard GR, Bauer TM, Velcheti V, Lakhani NJ, Besse B, Park K, Patel JD, Cabanillas ME et al: A phase 1 study of LOXO-292, a potent and highly selective RET inhibitor, in patients with RET-altered cancers. Journal of Clinical Oncology 2018, 36(15_suppl):102-102.

57. Pillai RN, Behera M, Berry LD, Rossi MR, Kris MG, Johnson BE, Bunn PA, Ramalingam SS, Khuri FR. HER2 mutations in lung adenocarcinomas: a report from the Lung Cancer Mutation Consortium. Cancer. 2017;123(21): 4099-105.

58. Li BT, Shen R, Buonocore D, Olah ZT, Ni A, Ginsberg MS, Ulaner GA, Offin M, Feldman D, Hembrough $T$, et al. Ado-trastuzumab emtansine for patients with HER2-mutant lung cancers: results from a phase II basket trial. Journal of Clinical Oncology. 2018:36(24):2532-7.

59. Iwata H, Tamura K, Doi T, Tsurutani J, Modi S, Park H, Krop IE, Sagara Y, Redfern CH, Murthy RK et al: Trastuzumab deruxtecan (DS-8201a) in subjects with HER2-expressing solid tumors: long-term results of a large phase 1 study with multiple expansion cohorts. Journal of Clinical Oncology 2018, 36(15_suppl):2501-2501.

60. Modi S, Saura C, Yamashita T, Park YH, Kim SB, Tamura K, Andre F, Iwata H, Ito Y, Tsurutani J, et al. Trastuzumab deruxtecan in previously treated HER2positive breast cancer. N Engl J Med. 2020;382(7):610-21.

61. Lai WV, Lebas L, Barnes TA, Milia J, Ni A, Gautschi O, Peters S, Ferrara R, Plodkowski AJ, Kavanagh J et al: Afatinib in patients with metastatic or recurrent HER2-mutant lung cancers: a retrospective international multicentre study. European journal of cancer (Oxford, England : 1990) 2019 109:28-35.

62. Hamilton EP, Barve MA, Bardia A, Beeram M, Bendell JC, Mosher R, Hailman E, Bergstrom DA, Burris HA, Soliman HH: Phase 1 dose escalation of XMT1522, a novel HER2-targeting antibody-drug conjugate (ADC), in patients (pts) with HER2-expressing breast, lung and gastric tumors. Journal of Clinical Oncology 2018, 36(15_suppl):2546-2546.

63. Wang Y, Jiang T, Qin Z, Jiang J, Wang Q, Yang S, Rivard C, Gao G, Ng TL, Tu $M M$, et al. HER2 exon 20 insertions in non-small-cell lung cancer are sensitive to the irreversible pan-HER receptor tyrosine kinase inhibitor pyrotinib. Annals of oncology : official journal of the European Society for Medical Oncology. 2019;30(3):447-55.

64. Gao G, Li X, Wang Q, Zhang Y, Chen J, Shu Y, Hu Y, Fan Y, Fang J, Chen G et al: Single-arm, phase II study of pyrotinib in advanced non-small cell lung cancer (NSCLC) patients with HER2 exon 20 mutation. Journal of Clinical Oncology 2019, 37(15_suppl):9089-9089.

65. Govindan R FM, Price T, et al: Phase 1 study of safety, tolerability, PK and efficacy of AMG 510, a novel KRAS G12C inhibitor, evaluated in NSCLC. IASLC 20th World Conference on Lung Cancer; September 7-10, 2019; Barcelona, Spain Abstract OA0202 2019.

66. Fakih M, O'Neil B, Price TJ, Falchook GS, Desai J, Kuo J, Govindan R, Rasmussen E, Morrow PKH, Ngang J et al: Phase 1 study evaluating the safety, tolerability, pharmacokinetics (PK), and efficacy of AMG 510, a novel small molecule KRASG12C inhibitor, in advanced solid tumors. Journal of Clinical Oncology 2019, 37(15_suppl):3003-3003.

67. Christensen JG, Hallin J, Engstrom LD, Hargis L, Calinisan A, Aranda R, Briere DM, Sudhakar N, Bowcut V, Baer BR et al: The KRASG12C Inhibitor, MRTX849, Provides insight toward therapeutic susceptibility of KRAS mutant cancers in mouse models and patients. Cancer Discovery 2019:CD-19-1167.

68. Plummer ER, Cook N, Arkenau H-T, Melear JM, Redfern CH, Spira Al, Chung KY, Shapiro G, Haddad TC, Ramalingam SS et al: Dose expansion cohort of a phase I trial of M6620 (formerly VX-970), a first-in-class ATR inhibitor, combined with gemcitabine (Gem) in patients (pts) with advanced non-small cell lung cancer (NSCLC). Journal of Clinical Oncology 2018, 36(15_suppl):e21048-e21048.

69. Sarantopoulos J, Beg MS, Fotopoulos G, Taverna JA, Anthony SP, Weitman SD, Warner SL, Mouritsen L, Bearss D, Smith S et al: A phase 1a / 1b first-inhuman, open-label, dose-escalation, safety, pharmacokinetic, and pharmacodynamic study of oral TP-0903, a potent inhibitor of AXL kinase, administered daily for 21 days to patients with advanced solid tumors. Journal of Clinical Oncology 2018, 36(15_suppl):TPS2612-TPS2612.

70. Felip E, Brunsvig P, Vinolas N, Aix SP, Costa EC, Gomez MD, Perez JMT, Arriola E, Campelo RG, Spicer JF et al: A phase II study of bemcentinib (BGB324), a first-in-class highly selective AXL inhibitor, with pembrolizumab in pts with advanced NSCLC: OS for stage I and preliminary stage II efficacy. Journal of Clinical Oncology 2019, 37(15_suppl):9098-9098.

71. Rashdan S, Williams JN, Currykosky P, Fattah F, Padro J, Wnuk-Lipinska K, Gausdal G, Brown A, Micklem D, Holt RJ et al: A phase 1/2 dose escalation and expansion study of bemcentinib (BGB324), a first-in-class, selective AXL inhibitor, with docetaxel in patients with previously treated non-squamous NSCLC. Journal of Clinical Oncology 2018, 36(15_suppl):e21043-e21043.

72. Azaro A, Rodon J, Middleton MR, Baird RD, Herrmann R, Fiedler U, Haunschild J, Häuptle M, Hermann FJ, Schreiner S et al: First-in-class phase I study evaluating MP0250, a VEGF and HGF neutralizing DARPIN molecule, in patients with advanced solid tumors. Journal of Clinical Oncology 2018, 36(15_suppl):2520-2520.

73. AACR Project GENIE. Powering precision medicine through an international consortium. Cancer Discov. 2017;7(8):818-31.

74. Sholl LM, Aisner DL, Varella-Garcia M, Berry LD, Dias-Santagata D, Wistuba II, Chen H, Fujimoto J, Kugler K, Franklin WA, et al. Multi-institutional oncogenic driver mutation analysis in lung adenocarcinoma: the lung cancer mutation consortium experience. Journal of thoracic oncology: official publication of the International Association for the Study of Lung Cancer. 2015;10(5):768-77.

75. Haura EB, Cho BC, Lee JS, Han J-Y, Lee KH, Sanborn RE, Govindan R, Cho EK, Kim S-W, Reckamp KL et al: JNJ-61186372 (JNJ-372), an EGFR-cMet bispecific antibody, in EGFR-driven advanced non-small cell lung cancer (NSCLC). Journal of Clinical Oncology 2019, 37(15_suppl):9009-9009.

76. Sands JM, Shimizu T, Garon EB, Greenberg J, Guevara FM, Heist RS, Kobayashi F, Noguchi Y, Okajima D, Tajima N et al: First-in-human phase 1 study of DS-1062a in patients with advanced solid tumors. Journal of Clinical Oncology 2019, 37(15_suppl):9051-9051. 
77. Suresh S Ramalingam JL, Morten Mau-Sorensen, Fiona Thistlethwaite, Sarina Piha-Paul, Shirish Gadgeel, Yvette Drew, Pasi A Jänne, Aaron S. Mansfield, Guang Chen, Ulf Forssmann, Hrefna Kristin Johannsdottir, Nora Pencheva, Annette Ervin-Haynes, Ignace Vergote First-in-human phase 1/2 trial of antiAXL antibody-drug conjugate (ADC) enapotamab vedotin (EnaV) in advanced NSCLC IASLC 20th World Conference on Lung Cancer; September 7-10, 2019; Barcelona, Spain Abstract OA0205.

78. Sachdev JC, Maitland ML, Sharma M, Moreno V, Boni V, Kummar S, StringerReasor EM, Forero-Torres A, Lakhani NJ, Gibson B et al: PF-06647020 (PF7020), an antibody-drug conjugate (ADC) targeting protein tyrosine kinase 7 (PTK7), in patients (pts) with advanced solid tumors: Results of a phase I dose escalation and expansion study. Journal of Clinical Oncology 2018, 36(15 suppl):5565-5565.

79. Adjei AA, Bekaii-Saab TS, Berlin J, Philip PA, Mercade TM, Walter A, Cupit L, Liu R, Fields SZ, Holynskyj A: Phase 1b multi-indication study of the antibody drug conjugate anetumab ravtansine in patients with mesothelinexpressing advanced or recurrent malignancies. Journal of Clinical Oncology 2018, 36(15_suppl):TPS2607-TPS2607.

80. Ahnert JR, Taylor MH, O'Reilly EM, Zhang J, Doebele RC, Ben Y, Sharp LL, Boyle WJ, Chang C, Frey G et al: A phase 1/2 dose-escalation and expansion study of a conditionally active anti-AXL humanized monoclonal antibody (BA3011) in patients with advanced solid tumors. Journal of Clinical Oncology 2018, 36(15_suppl):TPS12126-TPS12126.

81. Banerji U, Cook N, Evans TRJ, Candilejo IM, Roxburgh P, Kelly CLS, Sabaratnam N, Passi R, Leslie S, Katugampola S et al: A cancer research UK phase I/lla trial of BT1718 (a first in class bicycle drug conjugate) given intravenously in patients with advanced solid tumours. Journal of Clinical Oncology 2018, 36(15_suppl):TPS2610-TPS2610.

82. Janne PA, Yu HA, Johnson ML, Vigliotti M, Shipitofsky N, Guevara FM, Chen S, Yu C: Phase 1 study of the anti-HER3 antibody drug conjugate U3-1402 in metastatic or unresectable EGFR-mutant NSCLC. Journal of Clinical Oncology 2018, 36(15_suppl):TPS9110-TPS9110.

83. Oiseth SJ, Aziz MS. Cancer immunotherapy: a brief review of the history, possibilities, and challenges ahead. Journal of Cancer Metastasis and Treatment. 2017;3(10):250-61.

84. Burnet M. Cancer; a biological approach. I. The processes of control. British medical journal. 1957;1(5022):779-86.

85. Dunn GP, Bruce AT, Ikeda H, Old LJ, Schreiber RD. Cancer immunoediting: from immunosurveillance to tumor escape. Nature immunology. 2002;3(11):991-8.

86. Brahmer J, Reckamp KL, Baas P, Crino L, Eberhardt WE, Poddubskaya E, Antonia S, Pluzanski A, Vokes EE, Holgado E, et al. Nivolumab versus docetaxel in advanced squamous-cell non-small-cell lung cancer. N Engl J Med. 2015;373(2):123-35

87. Lopes G, Wu Y-L, Kudaba I, Kowalski D, Cho BC, Castro G, Srimuninnimit V, Bondarenko I, Kubota K, Lubiniecki GM et al: Pembrolizumab (pembro) versus platinum-based chemotherapy (chemo) as first-line therapy for advanced/metastatic NSCLC with a PD-L1 tumor proportion score (TPS) $\geq$ 1\%: Open-label, phase 3 KEYNOTE-042 study. Journal of Clinical Oncology 2018, 36(18_suppl):LBA4-LBA4.

88. Socinski MA, Jotte RM, Cappuzzo F, Orlandi F, Stroyakovskiy D, Nogami N, Rodriguez-Abreu D, Moro-Sibilot D, Thomas CA, Barlesi F, et al. Atezolizumab for first-line treatment of metastatic nonsquamous NSCLC. N Engl J Med. 2018;378(24):2288-301.

89. Hellmann MD, Paz-Ares L, Bernabe Caro R, Zurawski B, Kim SW, Carcereny Costa E, Park K, Alexandru A, Lupinacci L, de la Mora JE, et al. Nivolumab plus ipilimumab in advanced non-small-cell lung cancer. N Engl J Med. 2019:381(21):2020-31.

90. Wang J, Zhao J, Wang Z, Ma Z, Cui J, Shu Y, Liu Z, Cheng Y, Leaw S, Xia F et al: Tislelizumab, an investigational anti-PD-1 antibody, combined with chemotherapy as first-line treatment for lung cancer in Chinese patients. Journal of Clinical Oncology 2019, 37(15_suppl):e14067-e14067.

91. Moreno V, Calvo E, Garcia MEO, Gil-Martin M, Aljumaily R, Papadopoulos KP, Rosen LS, Rietschel P, Mohan KK, Li J et al: Tolerability and antitumor activity of cemiplimab, a human monoclonal anti-PD-1, in patients with non-small cell lung cancer (NSCLC): Interim data from a phase I dose escalation and NSCLC expansion cohort. Journal of Clinical Oncology 2019, 37(8_suppl):116-116.

92. Yang J, Yang S, Song H, Han X, Han Y, Jiang S, Yao J, Zhang Z, Zhang S, Liu $P$ et al: Phase 1 trial of JS001, a monoclonal antibody targeting programed death-1 (PD-1) in patients with advanced or recurrent malignancies. Journal of Clinical Oncology 2018, 36(15_suppl):e15108-e15108.
93. C. Lin MT, V. Boni, P.F. Brunsvig,et al: Phase $1 / / I$ study of spartalizumab (PDR001), an anti-PD1 mAb, in patients with advanced melanoma or nonsmall cell lung cancer. Annals of Oncology (2018) 29 (suppl_8): viii400viii441 101093/annonc/mdy288 2018

94. Vansteenkiste J, Felip E, Shepherd F, Paz-Ares L, Barlesi F, Burgers S, Cai C, Kiertsman F, Scott J, McCulloch T et al: P2.04-013 ElevatION:NSCLC-101; A phase $1 \mathrm{~b}$ study of PDR001 combined with chemotherapy in PD-L1 unselected, metastatic NSCLC patients. Journal of Thoracic Oncology 2017, 12(11):S2402.

95. Zhou C, Gao G, Wang YN, Zhao J, Chen G, Liu Z, Gu K, Huang M, He J, Chen J et al: Efficacy of PD-1 monoclonal antibody SHR-1210 plus apatinib in patients with advanced nonsquamous NSCLC with wild-type EGFR and ALK. Journal of Clinical Oncology 2019, 37(15_suppl):9112-9112.

96. Siglec-15: An attractive immunotherapy Target. Cancer Discov 2020, 10(1):7-8

97. Lam VK, Hong DS, Heymach J, Blumenschein GR, Creelan BC, Bradbury PA, Butler MO, Gainor JF, Govindan R, Johnson ML et al: Initial safety assessment of MAGE-A10c796TCR T-cells in two clinical trials. Journal of Clinical Oncology 2018, 36(15_suppl):3056-3056.

98. Sarnaik A, Khushalani NI, Chesney JA, Kluger HM, Curti BD, Lewis KD, Thomas SS, Whitman ED, Hamid O, Lutzky J et al: Safety and efficacy of cryopreserved autologous tumor infiltrating lymphocyte therapy (LN-144, lifileucel) in advanced metastatic melanoma patients who progressed on multiple prior therapies including anti-PD-1. Journal of Clinical Oncology 2019, 37(15 suppl):2518-2518.

99. Jazaeri AA, Zsiros E, Amaria RN, Artz AS, Edwards RP, Wenham RM, Slomovitz BM, Walther A, Thomas SS, Chesney JA et al: Safety and efficacy of adoptive cell transfer using autologous tumor infiltrating lymphocytes (LN-145) for treatment of recurrent, metastatic, or persistent cervical carcinoma. Journal of Clinical Oncology 2019, 37(15_suppl):2538-2538.

100. Chiappori A, Williams CC, Creelan BC, Tanvetyanon T, Gray JE, Haura EB, Thapa R, Chen D-T, Beg AA, Boyle TA et al: Phase I/II study of the A2AR antagonist NIR178 (PBF-509), an oral immunotherapy, in patients (pts) with advanced NSCLC. Journal of Clinical Oncology 2018, 36(15 suppl):9089-9089.

101. Powderly JD, Souza PLd, Gutierrez R, Horvath L, Seitz L, Ashok D, Park A Walters MJ, Karakunnel JJ, Berry W et al: AB928, a novel dual adenosine receptor antagonist, combined with chemotherapy or AB122 (anti-PD-1) in patients (pts) with advanced tumors: preliminary results from ongoing phase I studies. Journal of Clinical Oncology 2019, 37(15_suppl):2604-2604.

102. Collins JM, Heery CR, Donahue RN, Palena C, Madan RA, Strauss J, GattiMays ME, Schlom J, Gulley JL, Bilusic M: Phase I trial of BMS-986253, an antiIL-8 monoclonal antibody, in patients with metastatic or unresectable solid tumors. Journal of Clinical Oncology 2018, 36(15_suppl):3091-3091.

103. Bermejo IM, Jaffee EM, Davar D, Cardarelli J, Williams D, Phillips P, Carleton M, Zhou M, Henau OD, Monga M et al: Phase $1 \mathrm{~b} / 2$ study of nivolumab in combination with an anti-IL-8 monoclonal antibody, BMS-986253, in a biomarker-enriched population of patients with advanced cancer. Journal of Clinical Oncology 2018, 36(15_suppl):TPS3109-TPS3109.

104. Kluger H, Weiss SA, Olszanski AJ, Schuchter L, Linette GP, Garland L, lannotti NO, Johnson M, Avsar E, Srivastava MK, et al. Abstract CT089: Phase Ib/II of CD40 agonistic antibody APX005M in combination with nivolumab (nivo) in subjects with metastatic melanoma (M) or non-small cell lung cancer (NSCLC). Cancer Research. 2019;79(13 Supplement):CT089.

105. Grilley-Olson JE, Curti BD, Smith DC, Goel S, Gajewski T, Markovic S, Rixe O, Bajor DL, Gutierrez M, Kuzel T et al: SEA-CD40, a non-fucosylated CD40 agonist: interim results from a phase 1 study in advanced solid tumors. Journal of Clinical Oncology 2018, 36(15_suppl):3093-3093.

106. Diab A, Hurwitz ME, Cho DC, Papadimitrakopoulou V, Curti BD, Tykodi SS, Puzanov I, Ibrahim NK, Tolaney SM, Tripathy D et al: NKTR-214 (CD122biased agonist) plus nivolumab in patients with advanced solid tumors: preliminary phase 1/2 results of PIVOT. Journal of Clinical Oncology 2018, 36(15_suppl):3006-3006.

107. Vaena DA, Chaves J, Vogelzang NJ, Matrana MR, Gabayan AE, Riese MJ, Cho DC, Tagliaferri MA, Zalevsky J, Xie S et al: PROPEL: A phase 1/2 trial of NKTR214 (CD122-biased agonist) combined with anti-PD-1 (pembrolizumab) or anti-PD-L1 (atezolizumab) in patients (pts) with advanced solid tumors. Journal of Clinical Oncology 2018, 36(15_suppl):TPS3115-TPS3115.

108. Wrangle JM, Velcheti V, Patel MR, Garrett-Mayer E, Hill EG, Ravenel JG, Miller JS, Farhad M, Anderton K, Lindsey K, et al. ALT-803, an IL-15 superagonist, in combination with nivolumab in patients with metastatic non-small cell lung 
cancer: a non-randomised, open-label, phase 1b trial. Lancet Oncol. 2018; 19(5):694-704.

109. Iversen TZ, Engell-Noerregaard L, Ellebaek E, Andersen R, Larsen SK, Bjoern J, Zeyher C, Gouttefangeas C, Thomsen BM, Holm B, et al. Long-lasting disease stabilization in the absence of toxicity in metastatic lung cancer patients vaccinated with an epitope derived from indoleamine 2,3 dioxygenase. Clinical Cancer Research. 2014;20(1):221-32.

110. Spicer J, Provencio M, Garrido Lopez P, Bosch-Barrera J, de Castro Carpeño FJ, Felip E, Trigo J, Viteri S, Coart E, Schmidt E et al: 180TiPAn open-label, randomized, phase I/II trial of IO102 and pembrolizumab, or IO102, pembrolizumab and chemotherapy, as first-line treatment for patients with metastatic non-small cell lung cancer. Annals of Oncology 2019, 30(Supplement_2).

111. Villaruz L, Schneider B, Bauer T, Spira A, D'Amato G, Wasser J, Balmanoukian A, Lara P, Olszanski A, Gajewski T et al: OA05.02 Epacadostat plus pembrolizumab in patients with non-small cell lung cancer: phase 1/2 results from ECHO-202/KEYNOTE-037. Journal of Thoracic Oncology 2018, 13(10):S330.

112. Hyman DM, Brana I, Spreafico A, Schram AM, Pandya NB, Hoffman K, Hallet R, Giblin P, Anido J, Ruano IH et al: A phase 1 study of MSC-1, a humanized anti-LIF monoclonal antibody, in patients with advanced solid tumors. Journal of Clinical Oncology 2018, 36(15_suppl):TPS2602-TPS2602.

113. Camidge DR, Gadgeel SM, Weems GA, Wilkins HJ, Johnson ML: A phase 1b trial of RORy agonist LYC-55716 in combination with pembrolizumab to evaluate safety, efficacy, and immune biomarker profiles in patients with metastatic non-small cell lung cancer. Journal of Clinical Oncology 2018, 36(15_suppl):TPS9111-TPS9111.

114. Chow LQM, Gainor JF, Lakhani NJ, Chung HC, Lee K-W, Lee J, LoRusso P, Bang Y-J, Hodi FS, Fanning P et al: A phase I study of ALX148, a CD47 blocker, in combination with established anticancer antibodies in patients with advanced malignancy. Journal of Clinical Oncology 2019, 37(15_suppl):2514-2514.

115. Ghosh S, Sharma G, Travers J, Kumar S, Choi J, Jun HT, Kehry M, Ramaswamy S, Jenkins D: TSR-033, a novel therapeutic antibody targeting LAG-3, enhances T-cell function and the activity of PD-1 blockade Molecular Cancer Therapeutics 2019, 18(3):632-641.

116. Davar D BP, Eroglu Z, et al:: A phase 1 study of TSR-022, an anti-TIM-3 monoclonal antibody, in combination with TSR-042 (anti-PD-1) in patients with colorectal cancer and post-PD-1 NSCLC and melanoma 2018 SITC Annual Meeting 2018.

117. Doger B: Initial results from a Phase II study (TACTI 002) in metastatic non small cell lung or head and neck carcinoma patients receiving eftilagimod alpha (soluble LAG 3 protein ) and pembrolizumab. 34th German Cancer Congress in Berlin 2020.

118. Ramlau R, Kowalski D, Szczylik C, Szczęsna A, Wiatr E, Demas S, Chao H, Roszkowski-Sliz K. P2.06-006 Phase I/II dose escalation study of L-DOS47 as a monotherapy in non-squamous non-small cell lung cancer patients: topic: phase I/II trials. Journal of Thoracic Oncology. 2017;12(1):S1071-2.

119. Rajan A, Strauss J, Orpia A, Gatti-Mays ME, Wagner E, Heery CR, Pico C, Gulley JL: A trial of CV301 in combination with anti-PD-1 therapy versus anti-PD-1 therapy in subjects with non-small cell lung cancer. Journal of Clinical Oncology 2018, 36(15_suppl):TPS9108-TPS9108.

120. Papachristofilou A, Hipp MM, Klinkhardt U, Fruh M, Sebastian M, Weiss C, Pless M, Cathomas R, Hilbe W, Pall G, et al. Phase Ib evaluation of a selfadjuvanted protamine formulated mRNA-based active cancer immunotherapy, Bl1361849 (CV9202), combined with local radiation treatment in patients with stage IV non-small cell lung cancer. J Immunother Cancer. 2019;7(1):38.

121. Gandhi L, Aufiero Ramirez K, Schwarzenberger P, Ricciardi T, Macri MJ, Ryan A, Venhaus RR: Phase $1 / 2$ study of mRNA vaccine therapy + durvalumab (durva) \pm tremelimumab (treme) in patients with metastatic non-small cell lung cancer (NSCLC). Journal of Clinical Oncology 2018, 36(15_suppl): TPS9107-TPS9107.

122. Havel L, Kolek V, Pesek M, Cernovská M, Bartunkova J, Spisek R, Pecen L, Krasnopolskaya I, Zemanova M, Investigators S: Dendritic-cell vaccine (DCVAC) with first-line chemotherapy in patients with stage IV NSCLC: final analysis of phase II, open label, randomized, multicenter trial. Journal of Clinical Oncology 2019, 37(15_suppl):9039-9039.

123. Hu-Lieskovan S, Ott PA, Naing A, Besada RH, Gates SJ, Kohler VR, Curran RR, Bushway ME, Scherer J, Balogh KN, et al. Abstract 942: The personalized vaccine, NEO-PV-01 with anti-PD1, induces neoantigen-specific de novo immune responses in patients with advanced metastatic melanoma: association with clinical outcomes. Cancer Research. 2019;79(13 Supplement):942.

124. Govindan R, Awad MM, Cleary LD, Moles MA, Gaynor R, Goldstein MJ, Spige DR: An open-label, phase 1b study of NEO-PV-01 with pembrolizumab plus chemotherapy in patients with advanced or metastatic nonsquamous nonsmall cell lung cancer. Journal of Clinical Oncology 2018, 36(15_suppl): TPS3134-TPS3134.

125. Hecht JR, Goldman JW, Hayes S, Balli D, Princiotta MF, Dennie JG, Heyburn J, Sands T, Sheeri S, Petit R, et al. Safety and immunogenicity of a personalized neoantigen-listeria vaccine in cancer patients. Cancer Research. 2019;79(13 Supplement):CT007.

126. Awad MM, Bruchec YL, Lu B, Miller J, Dumitru CD, Spira Al: Phase lb study: selective histone deacetylase (HDAC) inhibitor ACY-241 + nivolumab (Nivo) in advanced non-small cell lung cancer (NSCLC). Journal of Clinical Oncology 2019, 37(15_suppl):9029-9029.

127. Gandhi L, Janne PA, Opyrchal M, Ramalingam SS, Rybkin II, Hafez N, Raez LE, Gabrilovich D, Wang F, Ordentlich P et al: Efficacy and safety of entinostat (ENT) and pembrolizumab (PEMBRO) in patients with non-small cell lung cancer (NSCLC) previously treated with anti-PD-(L)1 therapy. Journal of Clinical Oncology 2018, 36(15_suppl):9036-9036.

128. Saltos AN, Tanvetyanon T, Williams CC, Haura EB, Creelan BC, Antonia SJ, Tchekmedyian N, Goas K, Mamplata T, Thapa R et al: Phase I/lb study of pembrolizumab and vorinostat in patients with metastatic NSCLC (mNSCLC). Journal of Clinical Oncology 2018, 36(15_suppl):9046-9046.

129. Patnaik A, Carvajal RD, Komatsubara KM, Britten CD, Wesolowski R, Michelson G, Alcantar O, Zhang C, Powell B, Severson P et al: Phase ib/2a study of PLX51107, a small molecule BET inhibitor, in subjects with advanced hematological malignancies and solid tumors. Journal of Clinical Oncology 2018, 36(15_suppl):2550-2550.

130. Juergens RA, Chu QS, Renouf DJ, Laurie SA, Purcea D, McWhirter E, Arndt D, Gelmon KA, Hilton J, Gavillet B et al: A dose-finding study of the SMAC mimetic Debio 1143 when given in combination with avelumab to patients with advanced solid malignancies. Journal of Clinical Oncology 2019, 37(15_ suppl):2599-2599.

\section{Publisher's Note}

Springer Nature remains neutral with regard to jurisdictional claims in published maps and institutional affiliations.

Ready to submit your research? Choose BMC and benefit from:

- fast, convenient online submission

- thorough peer review by experienced researchers in your field

- rapid publication on acceptance

- support for research data, including large and complex data types

- gold Open Access which fosters wider collaboration and increased citations

- maximum visibility for your research: over $100 \mathrm{M}$ website views per year

At $\mathrm{BMC}$, research is always in progress.

Learn more biomedcentral.com/submissions 